\title{
Prehnite-pumpellyite facies metamorphism in the Cenozoic Abanico Formation, Andes of central Chile (33 50 'S): chemical and scale controls on mineral assemblages, reaction progress and the equilibrium state
}

\author{
Marcia Muñoz ${ }^{1}$, Luis Aguirre', Mario Vergara' ${ }^{1}$, Alain Demant' ${ }^{2}$ Francisco Fuentes ${ }^{3}$, Andrés Fock \\ 1 Departamento de Geología, Universidad de Chile, Casilla 13518, Correo 21, Santiago, Chile. \\ marmunoz@ing.uchile.cl; luaguirr@ing.uchile.cl; mariover@ing.uchile.cl \\ 2 Laboratoire de Pétrologie Magmatique Université Aix-Marseille III, 13397 Marseille Cedex 20, France. \\ alain.demant@univ-cezanne.fr \\ 3 Los Acacios, Parcela 142-3, Paine, Chile. \\ franciscofuentes@netlandchile.com \\ 4 SQM Salar S.A., Aníbal Pinto 3228, Antofagasta, Chile. \\ andres.fock@sqm.com
}

\begin{abstract}
In the El Volcán and Rodeo de los Bueyes areas, Andean Principal Cordillera (east of Santiago; 3350'S), an Upper Oligocene-Lower Miocene volcanic series belonging to the Abanico Formation (Late Eocene-Early Miocene) is exposed. The rock successions outcropping in both areas, $c a$. 3,300 m total thickness, have been affected by very low-grade, non-deformative metamorphism in the prehnite-pumpellyite facies. This is represented by the widespread development of secondary mineral assemblages composed of epidote, mixed-layer chlorite-smectite, albite, quartz, white mica, and titanite. These mineral assemblages also contain pumpellyite, prehnite or prehnite+actinolite in a few samples. Chemical characteristics, such as low compositional variability of mixed-layer chlorite-smectite and actinolite independent from the metadomain where these phases are hosted, along with a high proportion of chlorite layers in the former, suggest that these phases closely represent the whole rock effective bulk composition. On the contrary, pumpellyite compositions show a higher variability and a strong metadomain control evidencing its lower equilibration kinetics and leaving only those that grow in the rock matrix as the more closely representative of a whole rock effective bulk compositional control. Mineral assemblages from both areas show evidence of having been formed during the same metamorphic event where reactions have ocurred equivalently between them. However, local differences in chemical variables controlling this process are recognizable. A higher $\mathrm{CO}_{2}$ concentration in the fluids during the metamorphism in the El Volcán area than in the Rodeo de los Bueyes area is suggested by the scarce development of prehnite and the ubiquitous presence of calcite in the metamorphic assemblages of the former. Pressure and temperature of this metamorphic event have been roughly estimated to be lower than $2-3 \mathrm{kbar}$ and $320^{\circ} \mathrm{C}$, respectively.
\end{abstract}


RESUMEN. Metamorfismo de facies prehnita-pumpellyita en la Formación Abanico del Cenozoico, Andes centrales de Chile ( $\left.33^{\circ} 50^{\prime} \mathrm{S}\right)$ : controles químicos y de escala sobre las asociaciones minerales, el progreso de la reacción y el estado de equilibrio. En las áreas de El Volcán y Rodeo de los Bueyes, Cordillera Principal al este de Santiago (3350'S), aflora una serie volcánica del Oligoceno Superior-Mioceno Inferior perteneciente a la Formación Abanico (Eoceno Tardío-Mioceno Temprano). Las sucesiones de roca expuestas en ambas áreas, de $c a$. $3.300 \mathrm{~m}$ de espesor total, fueron afectadas por metamorfismo no deformativo de muy bajo grado en facies prehnita-pumpellyita. Esto está representado en el desarrollo extensivo de arreglos de minerales secundarios formados por epidota, interestratificados de clorita-esmectita, albita, cuarzo, mica blanca, y titanita. Estos arreglos minerales contienen además pumpellyita, prehnita o prehnita+actinolita en algunas muestras. Las características químicas tales como una baja variabilidad composicional de los interestratificados de clorita-esmectita y actinolita independientemente del dominio donde se hospedan estas fases, junto con una alta proporción de capas de clorita en las primeras, sugieren que estas fases representan cercanamente la composición efectiva de la roca total. Por el contrario, la composición de las pumpellyitas muestra una mayor variabilidad y un fuerte control del metadominio donde éstas se desarrollan evidenciando una baja cinética de equilibrio y dejando sólo a aquellas desarrolladas en la matriz como formadas bajo un control composicional efectivo de la roca total. Los arreglos minerales de ambas áreas muestran evidencias de haberse formado bajo un mismo evento metamórfico bajo el cual las reacciones se han desarrollado de manera equivalente. Aún así se reconocen diferencias químicas locales que controlan este proceso. Una mayor concentración de $\mathrm{CO}_{2}$ en los fluidos durante el metamorfismo en el área de El Volcán, con respecto al área de Rodeo de los Bueyes, se ve representada en la presencia escasa de prehnita, y abundante de calcita, en sus asociaciones minerales. La presión y temperatura de este evento metamórfico han sido gruesamente estimadas en valores inferiores a $2-3 \mathrm{kbar}$ y $320^{\circ} \mathrm{C}$, respectivamente.

Palabras clave: Formación Abanico, Andes, Facies prehnita-pumpellyita, Cenozoico.

\section{Introduction}

Very low-grade metamorphism, traditionally considered as developed as a consequence of burial (Coombs, 1961) or diastathermal (Robinson, 1987) processes, is characterized by being a nondeformative process where recrystallization is only partial and occurs at low temperatures $\left(<400^{\circ} \mathrm{C}\right)$ and low pressures $(<4-5 \mathrm{kbar})$ to a maximum of greenschist facies (Frey and Robinson, 1999, and references therein). Under these conditions, commonly fine grained metamorphic recrystallization is usually incomplete and secondary minerals coexist with primary metastable phases leaving the rocks exposed to this process with numerous textural evidences of chemical disequilibrium. Compositional chemical variability of secondary minerals and different mineral assemblages developed within a single thin section scale are common features of this type of metamorphism which exemplify this situation. These features arise as a consequence of the strong compositional control exerted by local differences in effective bulk composition within a rock between different growing sites, or metadomains as matrix, amygdules, veins, etc., where the secondary recrystallization takes place. These characteristics have led many studies of low-grade metamorphic terrains to carefully consider the scale at which equilibrium has been attained in order to be able to identify the meaningful lowvariance metamorphic assemblages and secondary mineral compositional trends which may allow to define a metamorphic facies and to constraint the P-T conditions under which this process has developed (e.g., Coombs et al., 1976.; Cho et al., 1986; Bevins and Merriman, 1988; Springer et al., 1992; Beiersdorfer and Day, 1995). Thus, despite the widespread evidence of disequilibrium, this approach has proven to be extremely useful as a characteristic, as coherent mineral assemblages and element partitioning between coexisting mineral pairs that indicate an approach to equilibrium, arise subject to the scale at which equilibrium has been attained (e.g., Coombs et al., 1976.; Cho et al., 1986; Bevins and Merriman, 1988; Springer et al., 1992; Beiersdorfer and Day, 1995). Other factors may complicate further the study of low-grade metamorphism. The amount of fluid availability during the metamorphic event and its composition critically affect the composition and occurrence of particular secondary mineral phases. Additionally, due to the sluggish reactions taking place at these low pressures and temperatures, the secondary mineral compositions may not be in complete equilibrium with the effective bulk composition under which they develop. Their actual composition is more a reflection of the state at which the reaction has progressed during the metamorphic event. All 
these characteristics make the study of very lowgrade metamorphism a complex issue, especially when approached solely in a descriptive manner. In the last two decades there have been significant advances in the characterization and understanding of this type of metamorphism based on studies of mineral chemistry and thermodynamic modelling of these data (e.g., Frey et al., 1991; Powell et al., 1993; Beiersdorfer and Day, 1995). These advances have made low-grade metamorphism a useful tool in the process of quantifying pressure and temperature conditions for rock successions that have been affected by these processes.

The Andean Cordillera presents a widespread development of secondary mineral assemblages representative of sub-greenschist facies which have been recognized as products of burial metamorphism since early studies (Levi, 1969, 1970; Aguirre et al., 1978, 1989; Offler et al., 1980; Levi et al., 1989; Atherton and Aguirre, 1992). This is particularly the case in central Chilean Andes where numerous studies have addressed the lowgrade metamorphism affecting the $c a .12 \mathrm{~km}$ thick Meso-Cenozoic succession exposed there (Levi, 1969, 1970; Aguirre et al., 1978, 1989; Levi et al., 1989; Belmar, 2000; Bevins et al., 2003; Robinson et al., 2004). The early studies were primarily based on petrographic descriptions (Levi, 1969, 1970; Aguirre et al., 1978, 1989; Levi et al., 1989), and the incorporation of studies based on mineral chemistry in the last decade has greatly enhance our knowledge and understanding of this process in this area (Aguirre et al., 2000; Belmar, 2000; Bevins et al., 2003; Robinson et al., 2004; Fuentes, 2004). However, there is still a lack of chemical studies addressing in detail the individual lithostratigraphic formations comprising the Meso-Cenozoic succession, even though some have been carried out at a few localities (Aguirre et al., 2000; Belmar, 2000; Fuentes, 2004). The aim of this work is to study in detail the low-grade metamorphism affecting the Cenozoic Abanico Formation in the central Chilean Andes, throughout a large and continuous section exposure of this succession ( $33^{\circ} 50^{\prime} \mathrm{S}$, Fig. 1). For this a petrographic and chemical characterization of its secondary minerals and mineral assemblages was carried out studying the state of the reaction progress and the scale of the approach to equilibrium attained by these rocks as a consequence of this metamorphic event.

\section{Geological background}

The Andean Principal Cordillera in central Chile $\left(33^{\circ}-34^{\circ} \mathrm{S}\right)$ is composed mainly of Cenozoic volcanic and volcaniclastic continental rocks forming a N-Strending continuous belt. These Cenozoic deposits unconformably overlie Mesozoic marine and continental units, distributed in a narrow belt near the Chilean-Argentinian border (Fig. 1). Between $33^{\circ}$ and $34^{\circ} \mathrm{S}$, the Cenozoic deposits are known as the Abanico Formation (Aguirre, 1960; Klohn, 1960) of Upper Eocene-Lower Miocene age (Vergara et al., 1999; Charrier et al., 2002) and the Farellones Formation (Klohn, 1960) of Miocene age (Munizaga and Vicente, 1982; Vergara et al., 1988). The Abanico Formation shows two parallel N-S-oriented belts, separated by the overlying Farellones Formation (Fig. 1). The distribution of the Abanico Formation in two bands has given rise to the informal terminology of the Abanico West and Abanico East formations (e.g., Godoy et al., 1999; Nyström et al., 2003; Robinson et al., 2004; Muñoz et al., 2006). An unconformity and a hiatus of $c a$. 80 Ma separate the Abanico East formation deposits from the underlying Mesozoic units (Charrier et al., 2002).

Both belts of the Abanico Formation have been interpreted as having been deposited simultaneously along the two opposing flanks of a volcano-tectonic intermontane basin (Vergara and Drake, 1979), or as deposited in a N-S-oriented extensive and subsident intra-arc basin (Godoy et al., 1999; Charrier et al., 2002). The volcanism that characterizes this formation has been related to the subduction of the Nazca (Farallon) oceanic plate under South America (Kay et al., 1999, 2005; Kay and Mpodozis, 2002; Nyström et al., 2003; Fuentes, 2004). The basin, or basin system, was formed upon a $c a$. $30-35 \mathrm{~km}$ thick continental crust during Late Eocene-Early Miocene times (Kay et al., 1999, 2005; Charrier et al., 2002; Kay and Mpodozis, 2002; Nyström et al., 2003; Fuentes, 2004) and went through a tectonic inversion that began during the Early Miocene, probably around $21 \mathrm{Ma}$ (Charrier et al., 2002).

Average Abanico Formation thickness is of $c a$. 3,000 $\mathrm{m}$ and the deposition and subsidence of this succession generated very low-grade metamorphic mineral assemblages characteristic of extensional settings in all its rocks (Levi, 1969, 1970; Aguirre et al., 1978, 1989; Levi et al., 1989; Belmar, 2000; Bevins et al., 2003; Robinson et al., 2004). These mineral 


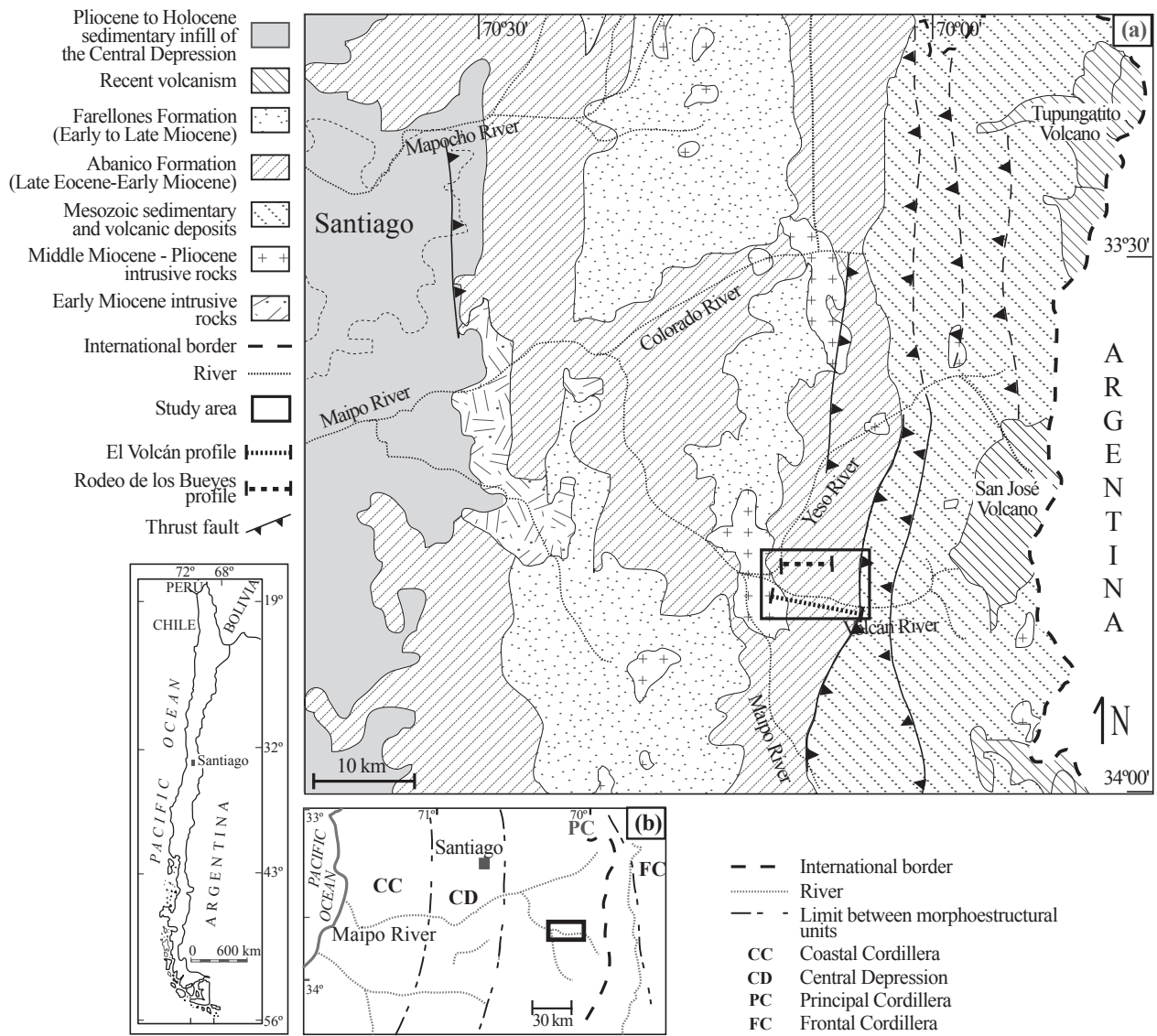

FIG. 1. Schematic geologic and morphostructural maps of the Andean Cordillera in central Chile. (a) Geologic map simplified and modified from SERNAGEOMIN (2002) and Fock (2005), (b) main subdivisions and morphostructural units according to Aubouin et al. (1973). The areas under study are shown within a black rectangle.

assemblages are typical of the prehnite-pumpellyite facies and include prehnite, pumpellyite, epidote and/ or actinolite along with the ubiquitous phases albite, quartz and mixed-layer chlorite-smectite (Levi, 1969, 1970; Belmar, 2000; Bevins et al., 2003; Robinson et al., 2004). Additionally, the presence of zeolites (laumontite) has been recognized towards the upper parts of this formation (Levi, 1970; Levi et al., 1989; Robinson et al., 2004). This, along with the progressive decrease in chlorite layers of the interstratified chlorite-smectite phyllosilicates from the Abanico Formation through the overlying Farellones Formation, has led to the recognition that the metamorphic grade decreases with the stratigraphic height and that the mineral assemblages in the upper portions of the Abanico Formation are representative of the zeolite facies (Levi, 1970; Levi et al., 1989; Robinson et al., 2004). Locally, mineral assemblages containing the zeolites yugawaralite and wairakite record a geothermal field-type metamorphism superimposed on the regional burial metamorphic event, which has been attributed to local hydrothermal systems (Vergara et al., 1993; Fuentes, 2004).

The present study was carried out on rocks of the Abanico East formation cropping out at $33^{\circ} 50^{\prime} \mathrm{S}$ between $70^{\circ} 12^{\prime}$ and $70^{\circ} 05^{\prime} \mathrm{W}$, in the Andean Principal Cordillera, east from Santiago (Fig. 1), where a continuous exposure of this formation allows tight stratigraphic control on sample collection. Two directly correlatable sections of the Abanico East formation exposed along river valleys were sampled. The main section covers the outcrops exposed along the El Volcán valley and sampling was performed on the $c a$. 3,300 m thick succession 
of Abanico Formation exposed there (Fig. 1). The second sampled section located approximately 5 $\mathrm{km}$ to the north of the previous one, at the Rodeo de Los Bueyes area, is correlated with the upper middle portion of the succession sampled in the El Volcán area (Figs. 1, 2). In these areas, the exposed Abanico East formation ranges in age from Late Oligocene to Early Miocene, and is composed of volcanic rocks ranging from basalts to andesites and minor dacites, with intercalated intermediate to acid volcaniclastic rocks (Baeza, 1999; Muñoz, 2005; Muñoz et al., 2006). The direct correspondence between these two sections has been shown in previous studies based on their areal and stratigraphic continuity (González, 1963; Godoy and Lara, 1994'; Muñoz, 2005; Fock, 2005). The main succession exposed in El Volcán river valley section comprises four units. Units I (base of the succession) and III are composed of a series of basaltic to andesitic lava flow with intercalations of volcanic breccias (flow breccias, lahars, detrital flows and pyroclastic deposits) and minor finely stratified epiclastic rocks, whereas units II and IV consist of a series of andesitic to dacitic ash tuffs with intercalations of epiclastic rocks and basaltic to andesitic lava flows (Muñoz, 2005; Muñoz et al., 2006). In both localities, the successions are intruded by minor dikes, sills and stocks of intermediate composition (Baeza, 1999; Muñoz, 2005; Muñoz et al., 2006). In the area of study the exposures of the Abanico Formation are in contect to the East with Mesozoic units along a thrust fault (Bustamante, 2001; Charrier et al., 2002) and to the west with the San Gabriel pluton of approximately $12 \mathrm{Ma}$ in age (Fig. 1; Drake et al., 1982; Kurtz et al., 1997).

\section{Methodology}

This study is based on petrographic descriptions of over 110 samples using standard optical microscopy. Mineral chemistry data were obtained by electron microprobe techniques for 23 of these samples, which correspond to 18 lavas, 3 tuffs, 1 stock and 1 sill, mainly basaltic to basaltic-andesitic, with minor andesitic and dacitic compositions. Wavelengthdispersive analyses for major elements were made on a Cameca SX-100 electron microprobe fitted with five spectrometers at the 'Service Commun Microsonde', Université de Montpellier, France. The standard operating conditions were $20 \mathrm{kV}$ and $10 \mathrm{nA}$ with an electron beam of $1 \mu \mathrm{m}$ width and integrated counting

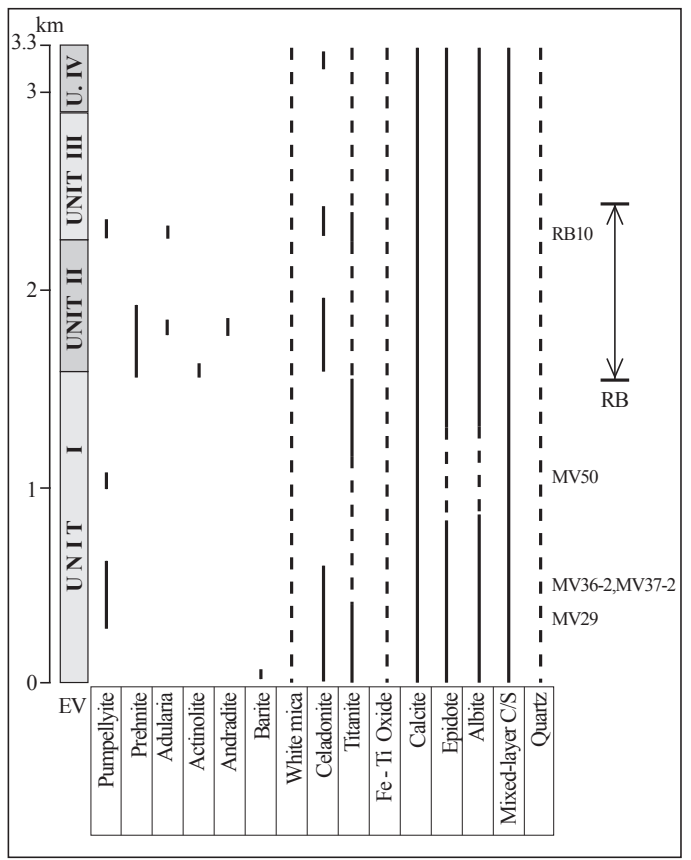

FIG. 2. Distribution of secondary minerals through the studied series shown relative to the stratigraphic column sampled in the El Volcán area (EV). The portion of the successions sampled in the Rodeo de los Bueyes area is highlighted (RB). Unit divisions after Muñoz et al. (2006). Solid lines indicate higher relative abundance. Stratigraphic location of samples with secondary assemblages containing pumpellyite plotted on the epidote projection diagrams are shown on the right column. C/S: mixed-layer chlorite-smectite; MV: samples from the El Volcán area; RB: samples from the Rodeo de los Bueyes area.

times of 20-30 secs. Synthetic and natural minerals were used as standards. Alkalis were determined first to minimize $\mathrm{Na}$ loss during measurements. A computer correction program (Merlet, 1994) was used to calculate the element concentrations. The accuracy of major element determinations is better than $\pm 5 \%$ of the total values. Minimum detection limits for the concentration estimates takes into account the fluctuation of the background measurement corrected by statistical confidence level factors, and the calculation is based on the equations provided by Ancey et al. (1978). The chemical analyses of secondary minerals are presented here in tables 1 to 5 displaying their mean composition within each sample but the complete dataset is available from the authors on request.

${ }^{1}$ Godoy, E.; Lara, L. 1994. El Teniente 2da Fase. Report (unpublished), CODELCO: 40 p. 


\section{Petrography}

Basaltic and basaltic andesite lava flows are porphyritic containing about $20 \mathrm{vol} \%$ phenocrysts of plagioclase $\left(\mathrm{An}_{50-70} \mathrm{Ab}_{30-48} \mathrm{Or}_{0-2}\right)$, clinopyroxene $\left(\mathrm{En}_{24-48} \mathrm{Wo}_{31-47} \mathrm{Fs}_{7-29}\right)$, olivine pseudomorphs and Fe-Ti oxides, in a holocrystalline to hypocrystalline, trachytic groundmass with similar mineralogy (Muñoz, 2005; Muñoz et al., 2006). Phenocrysts are typically 1-3 $\mathrm{mm}$ in size, although some plagioclase crystals are up to $1 \mathrm{~cm}$ in length. Andesite lava flows are relatively scarce in the succession and share similar petrographic characteristics. Analyzed volcaniclastic rocks correspond to flow tuff deposits composed of volcanic ash, fragments of pumice, crystals and crystal fragments, and lithic clasts. They are mainly ignimbritic pyroclastic welded flow deposits with a strong eutaxitic texture formed by abundant fragments of collapsed pumice. Analyzed subvolcanic rocks are basaltic andesitic to andesitic in composition. They are holocrystalline porphyritic rocks and contain about $10 \mathrm{vol} \%$ phenocrysts of plagioclase, clinopyroxene and amphibole in an intergranular groundmass. Apatite and less abundant zircon are common accessories in some of these rocks.

In order of abundance, secondary minerals present in these rocks are: calcite, epidote, albite, mixed-layer chlorite-smectite, quartz, white mica, titanite, celadonite, pumpellyite, prehnite, adularia, actinolite, barite, and andradite, plus abundant $\mathrm{Fe}-\mathrm{Ti}$ oxides. Figure 2 shows the distribution and relative abundance of these minerals through the stratigraphic column of the studied area. Petrographically, all the samples preserve their primary textural characteristics, secondary recrystallization never exceeds $60 \%$ in volume of the rock and is hosted in different domains. Primary minerals such as plagioclase, clinopyroxene and amphibole show little or no alteration, whereas olivine is always altered preferably to smectite and Fe-Ti oxides. Fragments of pumice and volcanic ash have been commonly transformed into mafic phyllosilicates.

\section{Mineral Chemistry}

\subsection{Mixed-layer chlorite-smectite}

Mixed-layer chlorite-smectite is persistently present throughout the entire succession (Fig. 2) and commonly occurs in amygdules and aggregates of the matrix. Although less commonly, it also occurs in all other metadomains, such as plagioclase, olivine and clinopyroxene phenocrysts and veinlets. These minerals show a wide spectrum of interference colours such as blue, violet, brown and green. Those with green colour have characteristically higher $\mathrm{Fe} /$ $(\mathrm{Fe}+\mathrm{Mg})>0.45$, at similar $\mathrm{Al}_{2} \mathrm{O}_{3}$ contents, than the rest. Microprobe analyses of mixed-layer chloritesmectite are presented in table 1.

The proportion of chlorite layers of the analyzed phyllosilicates $\left(\mathrm{X}_{\mathrm{C}}\right)$ ranges between 0.21-0.94. The lower values of this parameter are accompanied by a decrease of the non-interlayered cations (NIC) content down to 18.6 and an increase of interlayered cations (IC) and Si contents, up to 0.7 and 7.5, respectively (cations calculated per 28 oxygens). Although these parameters indicate considerable amounts of smectite layers in the analyzed phyllosilicates (Bettison and Schiffman, 1988; Schiffman and Fridleiffson, 1991), there is a general predominance of chlorite layers as shown by the $\mathrm{X}_{\mathrm{C}}$ parameter which is higher than 0.7 in $84 \%$ of the analyses. This is also reflected in the NIC versus $\mathrm{Al}_{\text {tot }}$ and IC versus Si diagram, where most mixed-layer chloritesmectite analyses plot near the end member clinochlore (Fig. 3a) and show low concentrations of IC and $\mathrm{Si}$ (Fig. 3b). Correlations between $X_{C}$ and stratigraphic height and between mineral composition and growing metadomains have not been observed. According to the classification scheme of Hey (1954), most of the mixed-layer chlorite-smectite analyses with $\mathrm{X}_{\mathrm{C}}>0.75$ correspond to picnochlorite, whereas those with lower $\mathrm{X}_{C}$ values classify as clinochlore and diabantite.

Even though overall chemical characteristics described for mixed-layer chlorite-smectite analyses are shared by both of the studied areas, there are local differences in composition. Although they largely overlap, mixed-layer chlorite-smectite from the El Volcán area extend to higher $\mathrm{Al}$ and lower $\mathrm{Si}$ contents than those from the Rodeo de los Bueyes area (Fig. 3a, b).

\subsection{Prehnite}

Prehnite is scarce in the El Volcán area, where it occurs only in one particular sample, whereas in the Rodeo de los Bueyes area it is more abundant being present in the majority of the samples studied. Prehnite is usually found as colourless irregular patches or radially developed crystals of low relief. It is present 


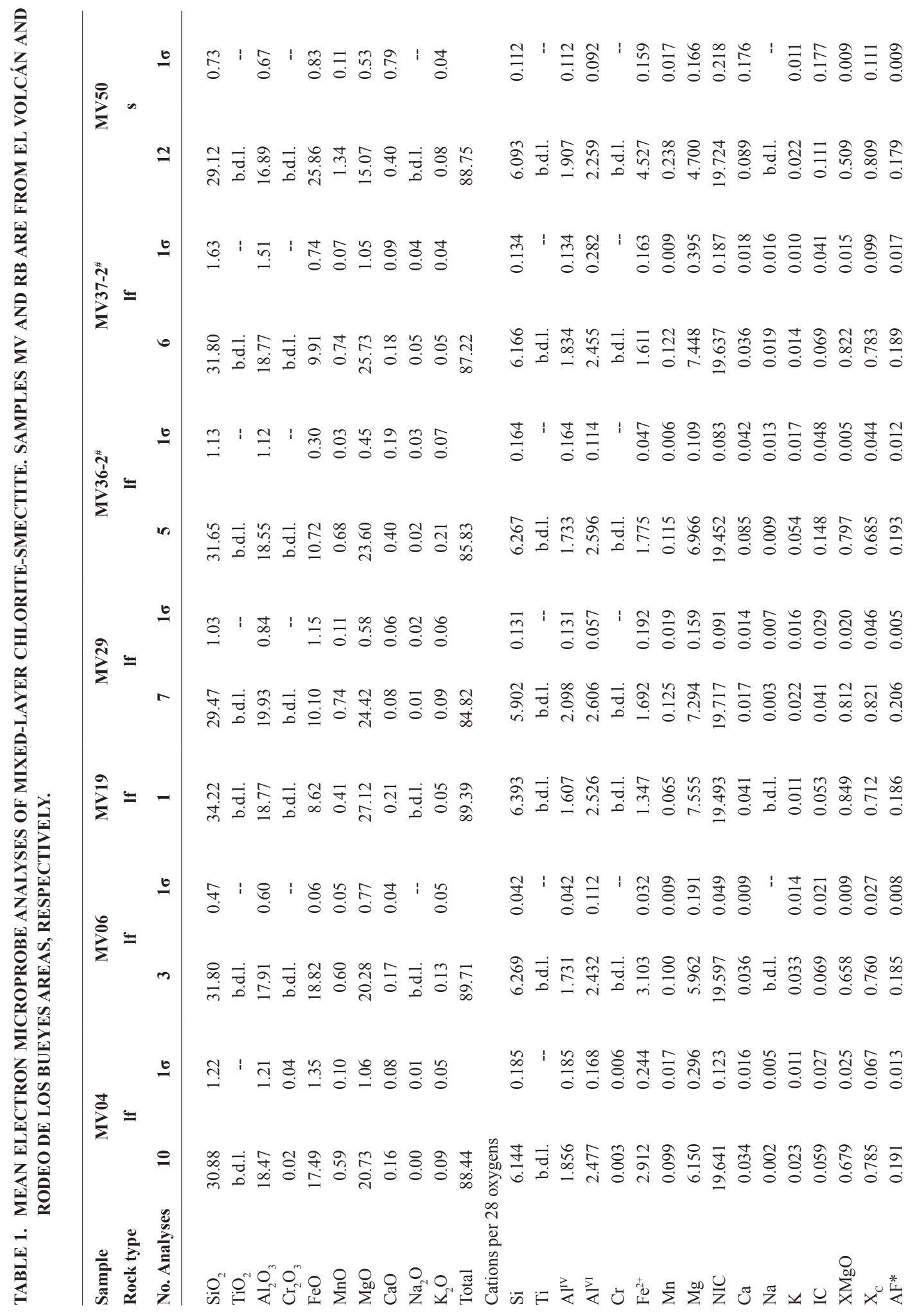









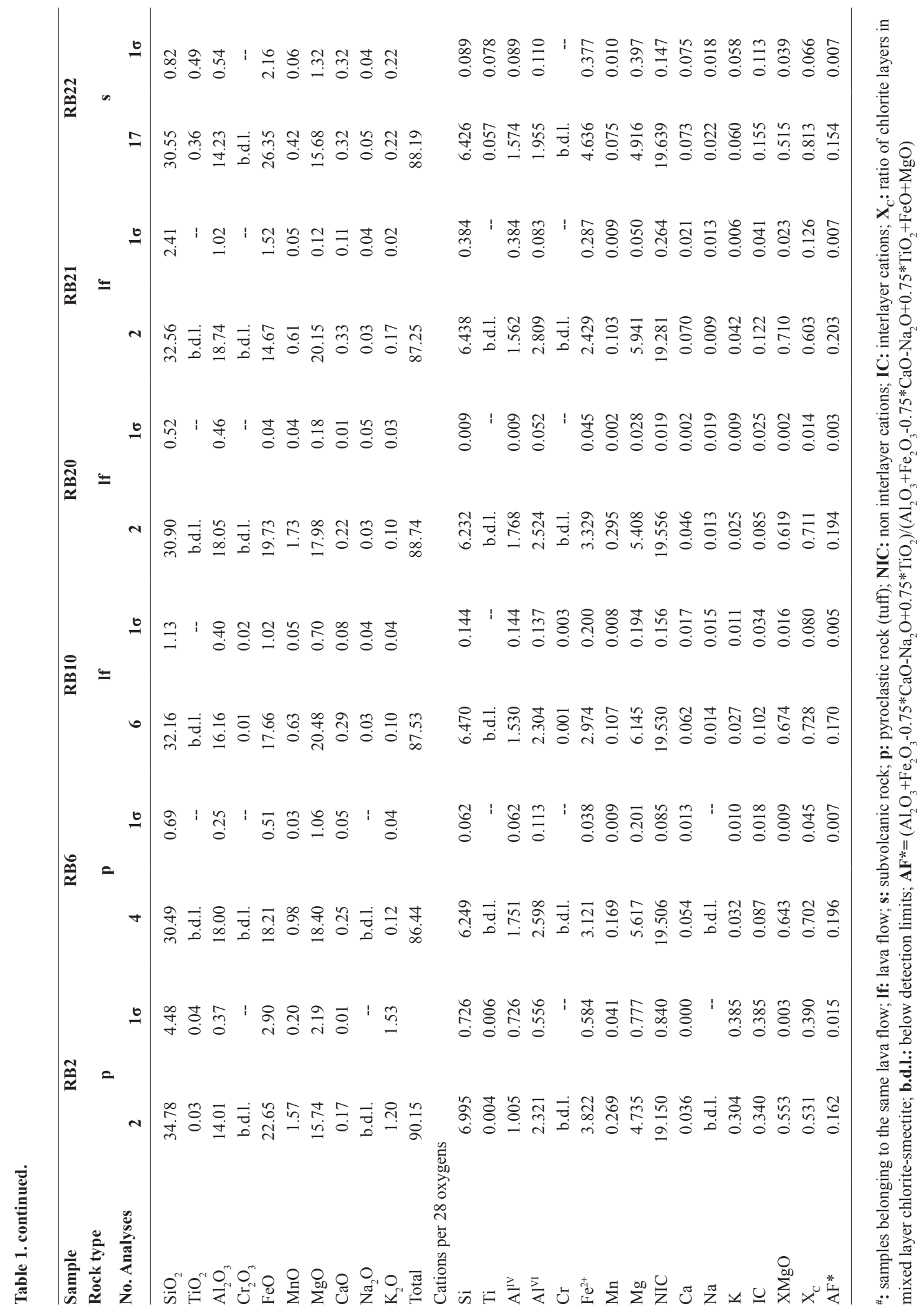



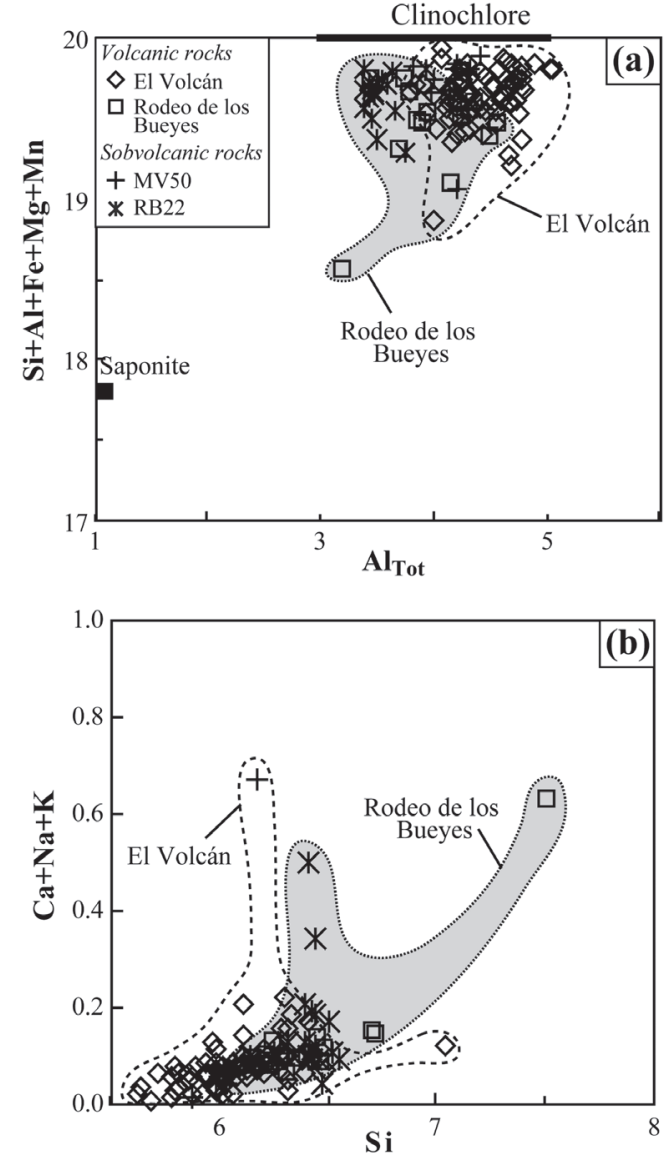

FIG 3. Mafic phyllosilicate compositions in terms of: (a) noninterlayer cation versus total $\mathrm{Al}$; and (b) interlayer cations versus Si content. Different compositions between both studied areas are highlighted. All analyses recalculated on the basis of a chlorite formula with 28 oxygens. In (a) ideal end members of saponite and clinochlore are shown by a solid square and a solid line, respectively.

in almost all metadomains, including amygdules, as partial replacement of feldspars and olivine, distributed through the rock matrix, or in veinlets. In all these domains prehnite is usually found in association with epidote, mixed-layer chlorite-smectite and albite. Prehnite $\mathrm{XFe}^{3+}$, calculated as the ratio $\mathrm{Fe}^{3+} /\left(\mathrm{Fe}^{3+}+\mathrm{Al}\right)$, ranges between 0-0.13 (Table 2).

\subsection{Actinolite}

Actinolite occurs in small amounts only in one andesitic stock in the Rodeo de los Bueyes area, where it is present as fibrous masses throughout the matrix of the rock or replacing clinopyroxene phenocrysts. Analyzed actinolites show limited compositional variations and low $\mathrm{Al}_{2} \mathrm{O}_{3}$ contents $(<1.7 \%$, Table 3$)$. These characteristics, and its occurrence without being exclusively restricted to replacement of primary mafic phases, suggest a metamorphic origin for this mineral (Coombs et al., 1976; Springer et al., 1992). Additionally, $\mathrm{K}_{\mathrm{D}}^{\mathrm{Mg}-\mathrm{Fe}}$ for actinolite-chlorite coexisting pairs ranges between 1.0 and 1.1, values consistent with those characteristic of low-grade metamorphic amphiboles (Robinson et al., 2004).

\subsection{Pumpellyite}

Pumpellyite is scarce throughout both studied areas. Its occurrence is largely restricted to samples from the lower parts of the succession exposed in the El Volcán area and one isolated sample in the upper middle part of the succession in the Rodeo de los Bueyes area (Fig. 2). These samples correspond to four units of basaltic lava flows and one sill of basaltic to basaltic andesitic composition. In these rocks pumpellyite forms assemblages with albite, epidote, mixed-layer chlorite-smectite and minor titanite and quartz. Microprobe analyses of pumpellyite are presented in table 4 .

Pumpellyite occurs as: (1) colourless prismatic crystals showing high relief in amygdules, (2) green, high relief, radial mineral aggregates in the matrix, and (3) brown, high relief amorphous or radial mineral aggregates partially to totally contained in plagioclase. $\mathrm{Fe} /(\mathrm{Fe}+\mathrm{Al})$ contents for these three occurrences are distinct, being near $0.15,0.23$, and 0.29 for colourless, green, and brown pumpellyites, respectively. Additionally, $\mathrm{MgO} /(\mathrm{MgO}+\mathrm{FeO})$ contents for pumpellyites partially to totally contained in plagioclase are between 0.1-0.2, and for those developed in the rest of the domains between 0.30.4 (Table 4). In terms of Al-Fe-Mg contents, most pumpellyites fall in the fields of pumpellyite from the Jonestown (prehnite-pumpellyite facies) and the Loèche terrains (pumpellyite-actinolite facies; Coombs et al., 1976; Liou and Ernst, 1979; Fig. 4, Table 4).

\subsection{Other minerals}

White potassic micas are present throughout the entire studied series and are preferently hosted 
TABLE 2. MEAN ELECTRON MICROPROBE ANALYSES OF PREHNITE. SAMPLES MV AND RB ARE FROM EL VOLCÁN AND RODEO DE LOS BUEYES AREAS, RESPECTIVELY.

\begin{tabular}{|c|c|c|c|c|c|c|c|c|}
\hline \multirow{3}{*}{$\begin{array}{l}\text { Sample } \\
\text { Rock type } \\
\text { No. Analyses }\end{array}$} & \multirow{2}{*}{\multicolumn{2}{|c|}{$\begin{array}{c}\text { MV90A } \\
\text { If }\end{array}$}} & \multirow{2}{*}{\multicolumn{2}{|c|}{$\begin{array}{c}\text { RB20 } \\
\text { If }\end{array}$}} & \multirow{2}{*}{\multicolumn{2}{|c|}{$\begin{array}{c}\text { RB21 } \\
\text { If }\end{array}$}} & \multirow{2}{*}{\multicolumn{2}{|c|}{$\begin{array}{c}\text { RB22 } \\
\text { s }\end{array}$}} \\
\hline & & & & & & & & \\
\hline & 3 & $1 \sigma$ & 4 & $1 \sigma$ & 10 & $1 \sigma$ & 5 & $1 \sigma$ \\
\hline $\mathrm{SiO}_{2}$ & 45.98 & 2.94 & 43.63 & 0.28 & 44.57 & 1.23 & 43.22 & 0.52 \\
\hline $\mathrm{TiO}_{2}$ & b.d.1. & -- & 0.01 & 0.03 & 0.09 & 0.07 & 0.05 & 0.08 \\
\hline $\mathrm{Al}_{2} \mathrm{O}_{3}$ & 22.99 & 2.04 & 21.28 & 0.47 & 22.57 & 1.19 & 22.14 & 0.25 \\
\hline $\mathrm{Fe}_{2} \mathrm{O}_{3}$ & 0.53 & 0.67 & 3.82 & 0.67 & 2.08 & 1.17 & 3.69 & 0.47 \\
\hline $\mathrm{MnO}$ & 0.12 & 0.04 & 0.13 & 0.03 & 0.08 & 0.06 & 0.03 & 0.04 \\
\hline $\mathrm{MgO}$ & b.d.l. & -- & 0.14 & 0.17 & 0.25 & 0.28 & 0.22 & 0.23 \\
\hline $\mathrm{CaO}$ & 26.27 & 1.65 & 26.36 & 0.04 & 25.71 & 1.82 & 26.38 & 0.37 \\
\hline $\mathrm{Na}_{2} \mathrm{O}$ & b.d.1. & -- & 0.03 & 0.04 & 0.21 & 0.46 & 0.04 & 0.06 \\
\hline $\mathrm{K}_{2} \mathrm{O}$ & 0.04 & 0.07 & 0.00 & 0.01 & 0.02 & 0.04 & 0.01 & 0.01 \\
\hline Total & 95.93 & & 95.41 & & 95.58 & & 95.78 & \\
\hline \multicolumn{9}{|c|}{ Cations per 11 oxygens } \\
\hline $\mathrm{Si}$ & 3.132 & 0.20 & 3.041 & 0.02 & 3.070 & 0.07 & 3.000 & 0.02 \\
\hline $\mathrm{Ti}$ & b.d.l. & -- & 0.001 & 0.00 & 0.005 & 0.00 & 0.002 & 0.00 \\
\hline $\mathrm{Al}^{\mathrm{IV}}$ & b.d.1. & -- & b.d.1. & -- & b.d.1. & -- & 0.010 & 0.02 \\
\hline $\mathrm{Al}^{\mathrm{VI}}$ & 1.846 & 0.16 & 1.748 & 0.04 & 1.832 & 0.09 & 1.801 & 0.02 \\
\hline $\mathrm{Fe}^{3+}$ & 0.027 & 0.03 & 0.200 & 0.04 & 0.108 & 0.06 & 0.193 & 0.02 \\
\hline $\mathrm{Mn}$ & 0.007 & 0.00 & 0.008 & 0.00 & 0.005 & 0.00 & 0.002 & 0.00 \\
\hline $\mathrm{Mg}$ & b.d.1. & -- & 0.014 & 0.02 & 0.025 & 0.03 & 0.023 & 0.02 \\
\hline $\mathrm{Ca}$ & 1.918 & 0.12 & 1.969 & 0.00 & 1.898 & 0.14 & 1.962 & 0.02 \\
\hline $\mathrm{Na}$ & b.d.l. & -- & 0.004 & 0.01 & 0.027 & 0.06 & 0.006 & 0.01 \\
\hline $\mathrm{K}$ & 0.003 & 0.01 & 0.000 & 0.00 & 0.002 & 0.00 & 0.001 & 0.00 \\
\hline $\mathrm{XFe}$ & 0.014 & 0.02 & 0.103 & 0.02 & 0.056 & 0.03 & 0.096 & 0.01 \\
\hline
\end{tabular}

If: lava flow; s: subvolcanic rock; b.d.l. : below detection limits; XFe : $\mathrm{Fe}^{3+} /\left(\mathrm{Fe}^{3+}+\mathrm{Al}\right)$.

in plagioclase phenocrysts. The presence of green potassic micas is restricted to particular samples, without a stratigraphic or metadomain control over its occurrence. According to the classification scheme by Pe-Piper (1985), based on a structural formulae on 14 oxygens, these micas correspond to: minerals with compositions intermediate between the end members muscovite-aluminoceladonite, minerals of the end member aluminoceladonite, and minerals with compositions of the end member muscovite. For these latter minerals, values of $\mathrm{Si} / \mathrm{Al}^{\mathrm{IV}}>3$ indicate the presence of a phengitic component in their structure (Kawachi, 1975; Coombs et al., 1976). Epidote, albite and titanite are ubiquitous minerals throughout the entire series. Pistacite contents $\left(\mathrm{XFe}^{3+}\right)$ of epidote range between 0.1-0.4 (Table 5). All the minerals described above are present throughout both studied areas and show no discernable compositional differences between them.
Anhydrous andradite and barite are scarce minerals, present in one sample each, which form part of secondary mineral assemblages in the Rodeo de los Bueyes and the El Volcán area, respectively. Adularia is relatively scarce and occurs only in secondary mineral assemblages of the Rodeo de los Bueyes area. Calcite is rare in the Rodeo de los Bueyes area, whilst ubiquitous in the El Volcán area. Although rocks near the contact with the San Gabriel pluton (less than $1 \mathrm{~km}$ ) show abundant calcite, which often obliterates their primary textures as the result of the intrusion, away from the influence of this pluton textural evidence suggests that calcite is part of the secondary mineral assemblages.

\section{Reaction progress and the equilibrium state}

In order to determine equilibrium mineral assemblages, which define the metamorphic facies, 


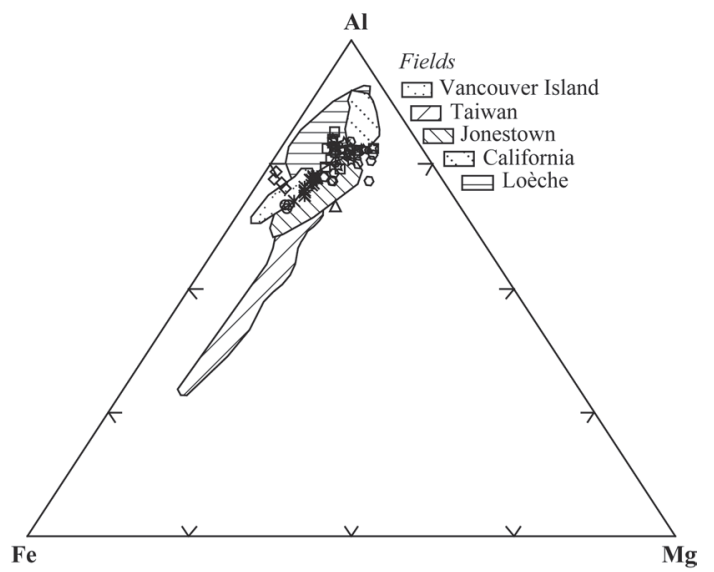

FIG. 4. Pumpellyite compositions in terms of Al-Fe-Mg. Fields from different metamorphic terrains after Coombs et al. (1976) and Liou and Ernst (1979) are shown for comparison. All analyses recalculated on the basis of a pumpellyite formula (Coombs et al., 1976) with 24.5 oxygens $\left(\mathrm{x}^{\prime}=1\right)$.

and to study meaningful mineral compositions and their variations is necessary to determine the scale at which equilibrium has been attained. In an equilibrium situation mineral assemblages and mineral compositions should reflect the effective bulk composition which frames their development. However, due to the sluggishness of reactions occurring at the low pressures and temperatures typical of low-grade metamorphism, these characteristics are usually more a reflection of the state at which the reaction has proceeded. Thus, to investigate this situation in the secondary mineral assemblages studied here we have addressed their composition and its variability. For simplicity, we have adopted the ratio $\mathrm{MgO} /(\mathrm{MgO}+\mathrm{FeO})$ as a proxy for these characteristics in mixed-layer chlorite-smectite, actinolite and pumpellyites since $\mathrm{Mg}$ and $\mathrm{Fe}$ are incorporated in all these minerals and its variation should be sensitive to variations in effective bulk composition. Additionally, compositional variability of this parameter is expressed as the relative standard deviation, or percent relative standard deviation, in order to have comparable measures between mixedlayer chlorite-smectite, actinolite and pumpellyite.

As mentioned earlier, the $X_{C}$ parameter for all analyzed mixed-layer chlorite-smectite shows a wide range of values between $0.21-0.94$, which is restricted to values $>0.7$ for $84 \%$ of the analyses (Fig. 3). For these minerals compositional variability at sample scale, in terms of $\mathrm{MgO} /(\mathrm{MgO}+\mathrm{FeO})$, is low and shows values of relative standard deviation between 0.3 and $7.6 \%$. This low variation is independent of the metadomain where mixed-layer chlorite-smectite is hosted or the secondary mineral assemblage in which it occurs. Accordingly, the same is seen for variations in the NIC, IC and $X_{C}$ parameters within each sample. These characteristics indicate that, although overall analyzed mixed-layer chlorite-smectite represent an advanced, but not complete, state of reaction progress of the transformation from smectite to chlorite, the reaction has proceeded equivalently at, least at a thin section scale being probably buffered by the whole rock effective bulk composition. Actinolite compositions, though only represented by four analyses of these minerals in different mineral aggregates, show a remarkable homogeneity with a constant value of $\mathrm{MgO} /(\mathrm{MgO}+\mathrm{FeO})$ of 0.51 . A different situation is seen in pumpellyite analyses whose compositional variation is greater than that shown by mixed-layer

TABLE 3. MEAN ELECTRON MICROPROBE ANALYSES OF ACTINOLITE FROM ONE SUBVOLCANIC ROCK FROM RODEO DE LOS BUEYES AREA.

\begin{tabular}{|c|c|c|}
\hline \multirow{3}{*}{$\begin{array}{l}\text { Sample } \\
\text { Rock type } \\
\text { No. Analyses }\end{array}$} & \multicolumn{2}{|c|}{ RB22 } \\
\hline & \multicolumn{2}{|c|}{$\mathbf{s}$} \\
\hline & 4 & $1 \sigma$ \\
\hline $\mathrm{SiO}_{2}$ & 52.77 & 0.88 \\
\hline $\mathrm{TiO}_{2}^{2}$ & 0.12 & 0.04 \\
\hline $\mathrm{Al}_{2} \mathrm{O}_{3}$ & 1.68 & 0.15 \\
\hline $\mathrm{FeO}$ & 20.13 & 0.47 \\
\hline $\mathrm{MnO}$ & 0.94 & 0.15 \\
\hline $\mathrm{MgO}$ & 11.90 & 0.45 \\
\hline $\mathrm{CaO}$ & 10.00 & 0.65 \\
\hline $\mathrm{Na}_{2} \mathrm{O}$ & 0.48 & 0.07 \\
\hline $\mathrm{K}_{2} \mathrm{O}$ & 0.12 & 0.02 \\
\hline Total & 98.16 & \\
\hline \multicolumn{3}{|c|}{ Cations per 23 oxygens } \\
\hline $\mathrm{Si}$ & 7.813 & 0.092 \\
\hline $\mathrm{Ti}$ & 0.014 & 0.004 \\
\hline $\mathrm{Al}$ & 0.294 & 0.027 \\
\hline $\mathrm{Fe}^{2+}$ & 2.493 & 0.072 \\
\hline $\mathrm{Mn}$ & 0.118 & 0.018 \\
\hline $\mathrm{Mg}$ & 2.627 & 0.112 \\
\hline $\mathrm{Ca}$ & 1.583 & 0.091 \\
\hline $\mathrm{Na}$ & 0.139 & 0.019 \\
\hline $\mathrm{K}$ & 0.023 & 0.005 \\
\hline $\mathrm{XMgO}$ & 0.513 & 0.004 \\
\hline $\mathrm{Mg} / \mathrm{Fe}$ & 1.054 & 0.018 \\
\hline
\end{tabular}

s: subvolcanic rock; $\mathbf{X M g O}: \mathrm{Mg} /(\mathrm{Fe}+\mathrm{Mg})$ 
TABLE 4. MEAN ELECTRON MICROPROBE ANALYSES OF PUMPELLYITE. SAMPLES MV AND RB ARE FROM EL VOLCÁN AND RODEO DE LOS BUEYES AREAS, RESPECTIVELY. STRUCTURAL FORMULAE CALCULATED ASSUMING 24.5 OXYGENS, $X^{\prime}=1$ AND ALL IRON AS Fe ${ }^{3+}$.

\begin{tabular}{|c|c|c|c|c|c|c|c|c|c|c|c|c|c|}
\hline \multirow{4}{*}{$\begin{array}{l}\text { Sample } \\
\text { Rock type } \\
\text { Metadomain } \\
\text { No. Analyses }\end{array}$} & \multirow{3}{*}{\multicolumn{2}{|c|}{$\begin{array}{c}\text { MV28 } \\
\text { If } \\
\text { a }\end{array}$}} & \multirow{4}{*}{$\begin{array}{c}\text { MV29 } \\
\text { If } \\
\text { m } \\
1\end{array}$} & \multirow{3}{*}{\multicolumn{2}{|c|}{$\begin{array}{c}\text { MV36-2 } \\
\text { If } \\
\text { p }\end{array}$}} & \multirow{3}{*}{\multicolumn{2}{|c|}{$\begin{array}{c}\text { MV37 } \\
\text { If } \\
\text { a }\end{array}$}} & \multirow{3}{*}{\multicolumn{2}{|c|}{$\begin{array}{c}\text { MV37-2 } \\
\text { If } \\
\text { m }\end{array}$}} & \multirow{3}{*}{\multicolumn{2}{|c|}{$\begin{array}{c}\text { MV50 } \\
\text { s } \\
\text { m }\end{array}$}} & \multirow{3}{*}{\multicolumn{2}{|c|}{$\begin{array}{c}\text { RB10 } \\
\text { If } \\
\text { p }\end{array}$}} \\
\hline & & & & & & & & & & & & & \\
\hline & & & & & & & & & & & & & \\
\hline & 13 & $1 \sigma$ & & 4 & $1 \sigma$ & 19 & $1 \sigma$ & 12 & $1 \sigma$ & 16 & $1 \sigma$ & 3 & $1 \sigma$ \\
\hline $\mathrm{SiO}_{2}$ & 37.87 & 0.33 & 36.98 & 36.50 & 0.27 & 37.52 & 0.57 & 36.53 & 0.57 & 36.03 & 0.39 & 39.75 & 0.53 \\
\hline $\mathrm{TiO}_{2}$ & 0.06 & 0.03 & b.d.l. & b.d.l. & -- & 0.01 & 0.02 & 0.05 & 0.04 & 0.02 & 0.03 & 0.02 & 0.03 \\
\hline $\mathrm{Fe}_{2} \mathrm{O}_{3}$ & 5.85 & 1.16 & 9.62 & 11.45 & 0.19 & 5.10 & 0.63 & 5.64 & 0.85 & 8.96 & 0.63 & 12.24 & 0.11 \\
\hline $\mathrm{MnO}$ & 0.25 & 0.05 & 0.14 & 0.44 & 0.01 & 0.35 & 0.07 & 0.32 & 0.05 & 0.32 & 0.04 & 0.25 & 0.02 \\
\hline $\mathrm{MgO}$ & 2.90 & 0.57 & 3.05 & 0.75 & 0.30 & 2.68 & 0.42 & 2.35 & 0.53 & 1.92 & 0.09 & 1.77 & 0.08 \\
\hline $\mathrm{CaO}$ & 23.18 & 0.23 & 23.08 & 21.60 & 0.30 & 22.76 & 0.42 & 22.69 & 0.16 & 22.15 & 0.27 & 18.56 & 0.92 \\
\hline $\mathrm{Na}_{2} \mathrm{O}$ & 0.02 & 0.02 & 0.06 & 0.02 & 0.03 & 0.01 & 0.02 & b.d.l. & -- & 0.01 & 0.02 & 0.10 & 0.11 \\
\hline $\mathrm{Si}$ & 6.111 & 0.034 & 6.115 & 6.049 & 0.018 & 6.102 & 0.044 & 6.022 & 0.042 & 6.118 & 0.035 & 6.460 & 0.092 \\
\hline $\mathrm{Ti}$ & 0.007 & 0.004 & b.d.1. & b.d.l. & -- & 0.001 & 0.003 & 0.006 & 0.005 & 0.002 & 0.003 & 0.002 & 0.004 \\
\hline $\mathrm{Al}$ & 4.489 & 0.136 & 4.045 & 4.485 & 0.036 & 4.622 & 0.080 & 4.690 & 0.117 & 4.281 & 0.081 & 4.121 & 0.059 \\
\hline $\mathrm{Fe}^{3+}$ & 0.790 & 0.162 & 1.331 & 1.587 & 0.022 & 0.693 & 0.086 & 0.779 & 0.122 & 1.273 & 0.093 & 1.664 & 0.009 \\
\hline $\mathrm{Mn}$ & 0.034 & 0.007 & 0.020 & 0.062 & 0.002 & 0.049 & 0.010 & 0.044 & 0.007 & 0.046 & 0.006 & 0.034 & 0.003 \\
\hline $\mathrm{Mg}$ & 0.698 & 0.135 & 0.751 & 0.184 & 0.072 & 0.651 & 0.099 & 0.577 & 0.123 & 0.487 & 0.023 & 0.429 & 0.017 \\
\hline $\mathrm{Ca}$ & 4.007 & 0.060 & 4.090 & 3.835 & 0.072 & 3.966 & 0.044 & 4.008 & 0.052 & 4.030 & 0.040 & 3.231 & 0.163 \\
\hline $\mathrm{Na}$ & 0.005 & 0.008 & 0.018 & 0.008 & 0.009 & 0.003 & 0.006 & b.d.l. & -- & 0.003 & 0.007 & 0.030 & 0.033 \\
\hline
\end{tabular}

\#: samples belonging to the same lava flow; lf: lava flow; s: subvolcanic rock; m: matrix hosted; p: plagioclase hosted; a: amygdule hosted; b.d.l.: below detection limits; Parameters $\mathrm{AF}^{*}, X \mathrm{MgO}$ and $\mathrm{Mg} / \mathrm{Fe}$ are calculated considering all iron in pumpellyite as $\mathrm{Fe}^{2+} ; \mathbf{A F}^{*}:\left(\mathrm{Al}_{2} \mathrm{O}_{3}+\mathrm{Fe}_{2} \mathrm{O}_{3}-0.75^{*} \mathrm{CaO}-\right.$ $\left.\mathrm{Na}_{2} \mathrm{O}+0.75 * \mathrm{TiO}_{2}\right) /\left(\mathrm{Al}_{2} \mathrm{O}_{3}+\mathrm{Fe}_{2} \mathrm{O}_{3}-0.75 * \mathrm{CaO}-\mathrm{Na}_{2} \mathrm{O}+0.75 * \mathrm{TiO}_{2}+\mathrm{FeO}+\mathrm{MgO}\right) ; \mathbf{X M g O}: \mathrm{Mg} /(\mathrm{Mg}+\mathrm{Fe})$.

chlorite-smectite and actinolite. Pumpellyites show a within sample relative standard deviation of the $\mathrm{MgO} /$ $(\mathrm{MgO}+\mathrm{FeO})$ ratio between 3.6 and $34.7 \%$. These high values are only slightly reduced when we consider just those in mineral assemblages containing mixedlayer chlorite-smectite. Additionally, unlike these last minerals, pumpellyite occurrence in different samples is always restricted to one particular metadomain. These characteristics suggest that pumpellyites correspond to only partially equilibrated mineral phases whose composition is highly conditioned by local effective bulk composition.

Pumpellyite and mixed-layer chlorite-smectite in secondary mineral assemblages hosted in plagioclase constitute an example of the differences between the state at which these two phases are able to equilibrate during the metamorphic event. Pumpellyites growing in this metadomain show high $\mathrm{FeO}$ and low $\mathrm{MgO}$ contents, resulting in a low $\mathrm{MgO} /(\mathrm{MgO}+\mathrm{FeO})$ ratio. Coombs et al. (1976) reported a similar case for pumpellyites occurring as inclusions in albitized plagioclase crystals from Loèche, in the Swiss Alps, and argued that growing sites within plagioclase crystals could be more easily reached by Fe than $\mathrm{Mg}$ ions preventing pumpellyites to reach the $\mathrm{Mg}$ : Fe ratio of the host rock. This could also be the result of an effective bulk composition control of the plagioclase crystals over the secondary minerals growing in it, since primary plagioclase in this rocks have contents of $\mathrm{FeO}$ between 0.19-1.62 and negligible contents 
TABLE 5. MEAN ELECTRON MICROPROBE ANALYSES OF EPIDOTE. SAMPLES MV AND RB ARE FROM EL VOLCÁN AND RODEO DE LOS BUEYES AREAS, RESPECTIVELY.

\begin{tabular}{|c|c|c|c|c|c|c|c|c|c|c|c|c|c|c|c|c|}
\hline \multirow{3}{*}{$\begin{array}{l}\text { Sample } \\
\text { Rock type } \\
\text { No. Analyses }\end{array}$} & \multirow{2}{*}{\multicolumn{2}{|c|}{$\begin{array}{c}\text { MV06 } \\
\text { If }\end{array}$}} & \multirow{2}{*}{\multicolumn{2}{|c|}{$\begin{array}{c}\text { MV19 } \\
\text { If }\end{array}$}} & \multirow{2}{*}{\multicolumn{2}{|c|}{$\begin{array}{c}\text { MV28 } \\
\text { If }\end{array}$}} & \multirow{2}{*}{\multicolumn{2}{|c|}{$\begin{array}{c}\text { MV29 } \\
\text { If }\end{array}$}} & \multirow{2}{*}{\multicolumn{2}{|c|}{$\begin{array}{c}\text { MV36-2 } \\
\text { If }\end{array}$}} & \multirow{2}{*}{\multicolumn{2}{|c|}{$\begin{array}{c}\text { MV37 }{ }^{\#} \\
\text { If }\end{array}$}} & \multirow{2}{*}{\multicolumn{2}{|c|}{$\begin{array}{c}\text { MV50 } \\
\text { s }\end{array}$}} & \multirow{2}{*}{\multicolumn{2}{|c|}{$\begin{array}{c}\text { MV57 } \\
\text { If }\end{array}$}} \\
\hline & & & & & & & & & & & & & & & & \\
\hline & 3 & $1 \sigma$ & 2 & $1 \sigma$ & 2 & $1 \sigma$ & 15 & $1 \sigma$ & 18 & $1 \sigma$ & 7 & $1 \sigma$ & 10 & $1 \sigma$ & 2 & $1 \sigma$ \\
\hline $\mathrm{SiO}_{2}$ & 38.25 & 0.56 & 37.65 & 0.69 & 38.19 & 0.77 & 36.91 & 0.32 & 37.13 & 0.59 & 38.19 & 0.26 & 37.47 & 0.52 & 38.47 & 2.51 \\
\hline $\mathrm{TiO}_{2}$ & 0.13 & 0.17 & 0.11 & 0.16 & 0.20 & 0.18 & 0.02 & 0.03 & 0.01 & 0.03 & 0.06 & 0.06 & 0.03 & 0.05 & 0.03 & 0.04 \\
\hline $\mathrm{Fe}_{2} \mathrm{O}_{3}$ & 14.75 & 0.88 & 14.49 & 0.16 & 13.36 & 4.63 & 12.02 & 1.72 & 12.80 & 0.96 & 13.14 & 1.81 & 16.91 & 1.70 & 12.31 & 4.80 \\
\hline $\mathrm{MnO}$ & 0.20 & 0.05 & 0.26 & 0.11 & 0.63 & 0.68 & 0.42 & 0.31 & 0.53 & 0.12 & 0.39 & 0.10 & 0.55 & 0.26 & 0.67 & 0.24 \\
\hline $\mathrm{MgO}$ & 0.07 & 0.07 & 0.08 & 0.04 & b.d.1 & -- & 0.01 & 0.02 & 0.06 & 0.08 & 0.06 & 0.09 & 0.02 & 0.05 & b.d.1 & -- \\
\hline $\mathrm{CaO}$ & 23.27 & 0.14 & 22.18 & 0.10 & 23.17 & 0.46 & 22.95 & 0.36 & 22.81 & 0.39 & 23.03 & 0.10 & 22.47 & 0.66 & 23.02 & 0.58 \\
\hline $\mathrm{Ti}$ & 0.008 & 0.010 & 0.007 & 0.010 & 0.012 & 0.011 & 0.001 & 0.002 & 0.001 & 0.002 & 0.003 & 0.004 & 0.002 & 0.003 & 0.002 & 0.002 \\
\hline $\mathrm{Al}$ & 2.117 & 0.082 & 2.076 & 0.026 & 2.186 & 0.306 & 2.286 & 0.118 & 2.209 & 0.050 & 2.188 & 0.107 & 1.967 & 0.127 & 2.289 & 0.237 \\
\hline $\mathrm{Cr}$ & b.d.1 & -- & b.d.l & -- & b.d.l & -- & b.d.l & -- & b.d.l & -- & b.d.l & -- & b.d.l & -- & b.d.l & -- \\
\hline $\mathrm{Fe}^{3+}$ & 0.872 & 0.059 & 0.881 & 0.007 & 0.793 & 0.287 & 0.729 & 0.108 & 0.776 & 0.051 & 0.782 & 0.110 & 1.024 & 0.113 & 0.728 & 0.312 \\
\hline $\mathrm{Mn}$ & 0.013 & 0.004 & 0.018 & 0.007 & 0.042 & 0.045 & 0.029 & 0.021 & 0.036 & 0.008 & 0.026 & 0.007 & 0.038 & 0.018 & 0.044 & 0.014 \\
\hline $\mathrm{Mg}$ & 0.009 & 0.008 & 0.010 & 0.005 & b.d.1 & -- & 0.001 & 0.002 & 0.007 & 0.010 & 0.007 & 0.010 & 0.003 & 0.006 & b.d.1 & -- \\
\hline $\mathrm{Ca}$ & 1.961 & 0.014 & 1.923 & 0.029 & 1.955 & 0.072 & 1.985 & 0.039 & 1.975 & 0.022 & 1.954 & 0.016 & 1.938 & 0.048 & 1.925 & 0.034 \\
\hline $\mathrm{XFe}$ & 0.292 & 0.021 & 0.298 & 0.004 & 0.266 & 0.098 & 0.242 & 0.037 & 0.260 & 0.017 & 0.263 & 0.037 & 0.342 & 0.039 & 0.240 & 0.098 \\
\hline
\end{tabular}

Table 5 continued.

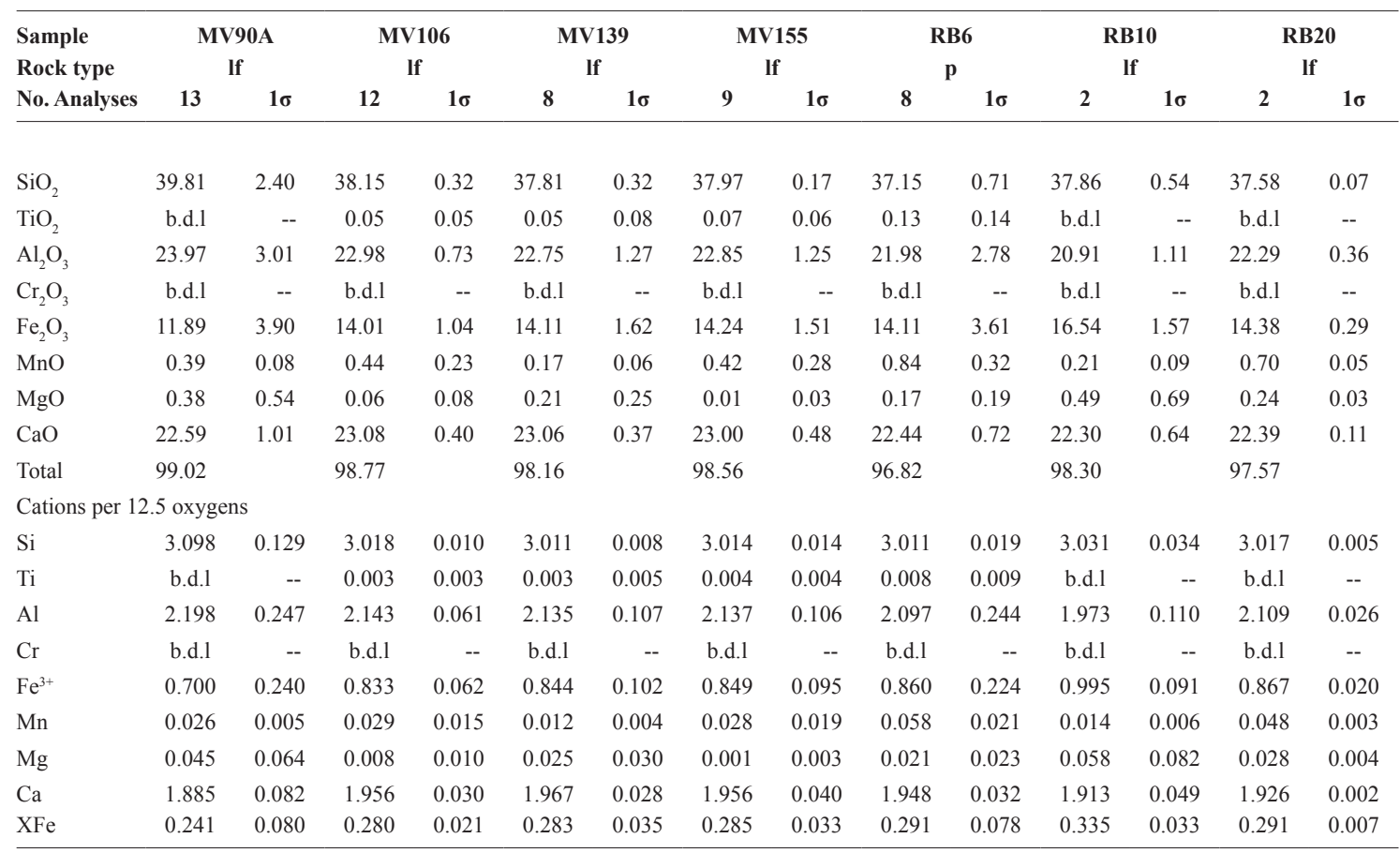

": samples belonging to the same lava flow; lf: lava flow; s: subvolcanic rock; p: pyroclastic rock (tuff); b.d.l.: below detection limits; XFe : Fe ${ }^{3+} /$ $\left(\mathrm{Fe}^{3+}+\mathrm{Al}\right)$. 
of $\mathrm{MgO}$ (Muñoz, 2005). Considering that within each rock mixed-layer chlorite-smectite shows a rather homogeneous composition, independent of the metadomain where they are hosted, solely an effective bulk composition or a differential diffusion control can not satisfactorily explain the compositions of plagioclase hosted pumpellyite, because this control should also be reflected in plagioclase hosted mixed-layer chlorite-smectite compositions which is not observed.

In rocks affected by low-grade metamorphism the development of different mineral assemblages or variable mineral composition within a thin section scale is primarily a product of local compositional control (see Beiersdorfer and Day, 1995 for a review). Other parameters being equal, as the amount of metamorphic alteration increases within a rock, the number of different effective bulk compositions decreases and there is a corresponding decrease in the number of observed mineral assemblages and the variability in mineral compositions (Springer et al., 1992). Coombs et al. (1976) indicated that initial nucleation of secondary phases may be highly influenced by local chemical conditions, but once nucleation is achieved, and under the presence of pore fluid, extensive stabilization of these minerals can be expected at least for cations in structurally favourable sites. The composition of pumpellyite and mixed-layer chlorite-smectite hosted in plagioclase observed here can be explained by the interplay of all these factors during the low-grade metamorphic event. In the initial stage of secondary mineral nucleation either the metadomain bulk composition or the differential diffusion, or both, are expected to be the primary control on the composition of newly formed minerals. Recrystallization, which progressively consumes the primary plagioclase and proceeds along with an increase in volume of the secondary mineral aggregates, is likely to reach a point where the dominant bulk composition is no longer buffered by the plagioclase crystal but by the rock matrix. Since mixed-layer chlorite-smectite has higher rates of diffusion than pumpellyite (Frey and Robinson, 1999) these minerals were probably able to equilibrate to the new compositional conditions while pumpellyites either retained their original imprint or were only partially equilibrated under the new effective bulk composition.

Mixed-layer chlorite-smectite, actinolite and pumpellyite show no textural evidence of disequi- librium in secondary mineral aggregates between minerals in physical contact. Additionally, the within sample partition coefficient $\mathrm{K}_{\mathrm{D}}^{\mathrm{Mg}-\mathrm{Fe}}$ of pumpellyitechlorite and actinolite-chlorite pairs is relatively constant between coexisting mineral pairs $\left(\mathrm{K}_{\mathrm{D}}^{\mathrm{Mg}-\mathrm{Fe}}\right.$ variation less than 0.04 , values indicated in figure 5). These characteristics suggest that although these minerals, especially pumpellyites, do not correspond to fully equilibrated phases, at a sample scale the reactions have proceeded in an equivalent manner. This is particularly the case at a metadomain scale between coexisting minerals in physical contact. Additionally, since mineral assemblages developed in the rock matrix are those that more closely represent the whole rock effective bulk composition this can be considered the closest to an equilibrium scale for the assemblages studied here.

\section{Epidote projection}

Mineral projections correspond to a graphic representation of mineral assemblages in a particular compositional space and in the study of very lowgrade metamorphism are widely used for evaluating the relations between mineral assemblages and effective bulk composition. The epidote projection is constructed by the reduction of the nine component system $\mathrm{Na}_{2} \mathrm{O}-\mathrm{MgO}-\mathrm{SiO}_{2}-\mathrm{CaO}-\mathrm{Fe}_{2} \mathrm{O}_{3}-\mathrm{FeO}-\mathrm{TiO}_{2}-\mathrm{H}_{2} \mathrm{O}$, in which most of the typical low-grade metamorphic mineral compositions can be expressed, in order to be able to analyze it in two dimensions. $\mathrm{Al}_{2} \mathrm{O}_{3}$ and $\mathrm{Fe}_{2} \mathrm{O}_{3}$ are combined as a single component and mineral compositions are projected from the mineral phases albite, epidote, quartz and $\mathrm{H}_{2} \mathrm{O}$ on the plane $\mathrm{AF}$ (expression indicated in figure 5) $-\mathrm{Mg} /(\mathrm{Mg}+\mathrm{Fe})$. In this type of projection, the absence of crossing tielines between mineral pairs is interpreted as indicating formation under the same intensive metamorphic conditions, in which case differences in metamorphic mineral compositions are related only to differences in bulk composition (Springer et al., 1992; Beiersdorfer, 1993). However interpretation of crossing tielines is not always unambiguous because, as noted by Beiersdorfer and Day (1995), these can be the result of having combined oxides or, more importantly, because of the compositional variability of the mineral phases used for the projection.

The epidote projection has been used here over chlorite-pumpellyite and chlorite-actinolite coexist- 

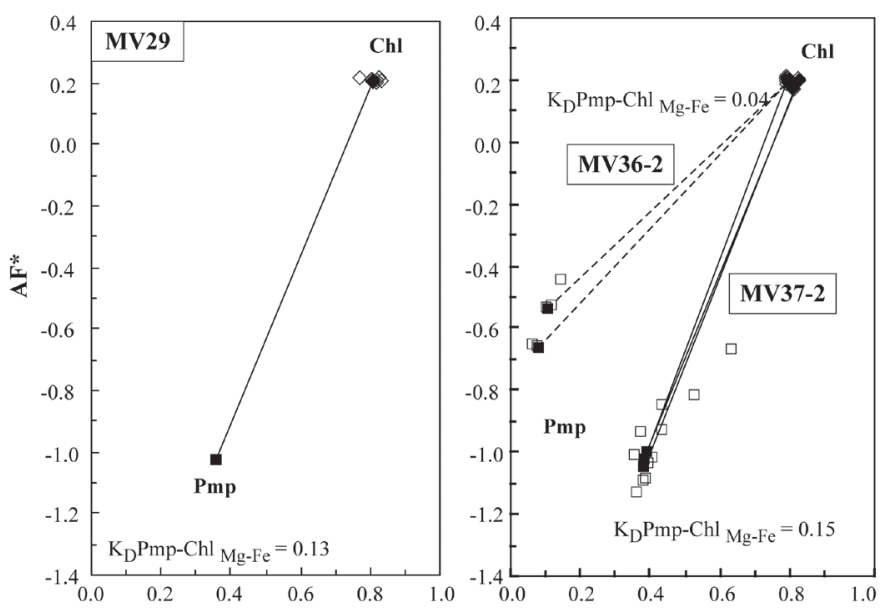

\section{SYMBOLS \\ Analyses of coexisting mineral pairs \\ - Chlorite (Chl) \\ - Pumpellyite (Pmp) \\ A Actinolite (Act)}

Analyses of individual minerals

(not in physical contact)

$\diamond$ Chlorite (Chl)

$\checkmark$ Pumpellyite (Pmp)

$\triangle$ Actinolite (Act)

Tielines of chlorite-pumpellyite coexisting pairs

-.- Plagioclase hosted

— Matrix hosted
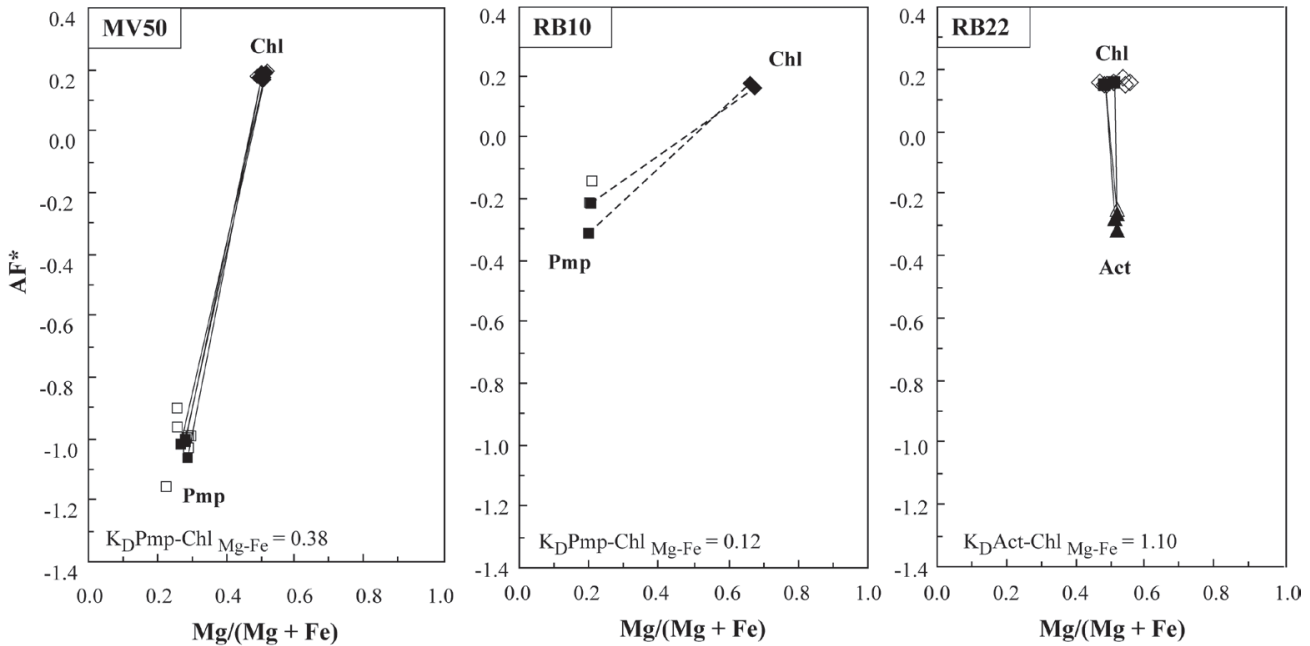

FIG. 5. Epidote projection for El Volcán and Rodeo de los Bueyes samples. AF* $=100 /\left(\mathrm{Al}_{2} \mathrm{O}_{3}+\mathrm{Fe}_{2} \mathrm{O}_{3}+0.75 * \mathrm{CaO}-\mathrm{Na} \mathrm{O}_{2}+0.75 * \mathrm{TiO}\right)_{2} /$ $\left(\mathrm{Al}_{2} \mathrm{O}_{3}+\mathrm{Fe}_{2} \mathrm{O}_{3}-0.75 * \mathrm{CaO}-\mathrm{Na}_{2} \mathrm{O}+0.75 * \mathrm{TiO}_{2}+\mathrm{FeO}+\mathrm{MgO}\right)$. All iron in pumpellyite as $\mathrm{Fe}^{2+}$. Pmp: pumpellyite; Chl: chlorite; Act: actinolite.

ing pairs that are in physical contact (Fig. 5). For the projection we have chosen to retain iron in all phases as FeO, following Bevins and Robinson (1995) who indicated that an imperfect estimation of $\mathrm{Fe}^{3+}$ in pumpellyite would only generate distortion. Additionally, Beiersdorfer (1993) have indicated that the estimation of $\mathrm{Fe}^{3+}$ seems to have no profound effect on this mineral projection. Six samples have been represented in the epidote projection, five of them containing pumpellyite and one containing actinolite and prehnite in mineral assemblages with mixed-layer chlorite-smectite, epidote, quartz and albite (Fig. 5). Four of the former samples belong to the El Volcán area while the remaining two belong to the Rodeo de los Bueyes area (Fig. 2). Figure 5 displays epidote projections for each individual sample containing chlorite-pumpellyite and chlorite-actinolite coexisting pairs, except for samples MV36-2 and MV37-2 which have been plotted together as they belong to different samples from the same lava flow. Also plotted on these projections are compositions of individual chlorite, pumpellyite and actinolite minerals within each sample which are not in physical contact (Fig. 5).

In the mineral projection, all samples display nonintersecting and near parallel tielines and show narrow compositional ranges for chlorites and actinolites and larger spreads for pumpellyites (Fig. 5), whether 
these minerals coexist or not. Samples MV36-2 and MV37-2 show almost parallel tielines within each sample but not when considered together (Fig. 5). Pumpellyites from sample MV37-2 are hosted in amygdules while those in sample MV36-2 are hosted in plagioclase. As these latter pumpellyites are poorer in $\mathrm{MgO}$ and show a higher value of the $\mathrm{AF}^{*}$ parameter, they produce a gentler slope for the chlorite-pumpellyite tielines in sample MV36-2 than in sample MV37-2, since chlorite compositions are similar in both samples (Fig. 5). These different slopes do not reflect different metamorphic events because both samples belong to the same lava flow. They are the result of the compositional control exerted by the metadomain where these minerals grow along with the slower equilibration kinetics of pumpellyite minerals during the metamorphic event. In this case, compositions of chlorite-pumpellyite mineral pairs hosted in the matrix are probably a nearer reflection of the whole rock effective bulk composition, while compositions of those mineral pairs hosted in plagioclase are biased by the non equilibrated nature of pumpellyites growing in this metadomain.

Epidote projections for mean chlorite-pumpellyite compositions of each sample investigated display two groups of contrasting slopes which are independent of the area considered (Fig. 6). The steep slope group corresponds to these minerals hosted in the matrix, whereas the shallow slope group corresponds to those hosted in plagioclase. It is remarkable that tielines of the pumpellyitechlorite pairs hosted in plagioclase remain parallel even in the case of samples from the different areas of El Volcán and Rodeo de los Bueyes. This suggests that mineral assemblages investigated have formed under the same metamorphic event and that reactions have ocurred equivalently in both areas.

\section{Mineral assemblages and metamorphic facies}

The most frequent mineral assemblage throughout both studied areas consists of mixed-layer chlorite-smectite+epidote, plus the ubiquitous phases albite, quartz, titanite and, in the El Volcán area, calcite. This assemblage is accompanied by either pumpellyite, prehnite or actinolite+prehnite in some samples. According to the metamorphic facies characterization of Liou et al. (1985) the assemblage epidote + pumpellyite \pm prehnite defines the prehnite-pumpellyite facies (Fig. 7). This assemblage, without prehnite, is present in several samples in the El Volcán area, being restricted to the lower parts of the succession. As indicated in many studies (Zen, 1961; Liou et al., 1987; Digel and Ghent, 1994), prehnite is a mineral whose formation is very sensitive to the $\mathrm{CO}_{2}$ content of fluids during metamorphism and for which even low $\mathrm{CO}_{2}$ activities would inhibit its formation. In this context, the ubiquitous presence of calcite in metamorphic mineral assemblages in the El Volcán area, in contrast with its scarcity in the Rodeo de los Bueyes area, suggests higher $\mathrm{CO}_{2}$ contents in the fluids during metamorphism at the former locality, most probably suppressing prehnite formation as observed. This same assemblage is very scarce in the Rodeo de los Bueyes area, having been found only in one sample. This may well be the result of the succession sampled in this area, which corresponds to the upper middle part of the series, whereas this assemblage seems to develop preferably in the lower portions of the general succession, as seen in the El Volcán area (Fig. 2). Thus, these secondary mineral assemblages are considered to be the result of prehnite-pumpellyite facies metamorphism at both localities studied here, as it has been previously established for the Abanico Formation in other areas in central Chile (Levi, 1969, 1970; Aguirre et al., 1978, 1989; Levi et al., 1989; Belmar, 2000; Bevins et al., 2003; Robinson et al., 2004). Additionally, pumpellyite-chlorite tielines for mineral pairs hosted in the matrix, which more closely represent the whole rock effective bulk composition, display a range of $\mathrm{K}_{\mathrm{D}}$ values between $0.13-0.38$ for a wide range of $\mathrm{MgO} /(\mathrm{MgO}+\mathrm{FeO}$ ) of $0.50-0.81$ (Fig. $5)$. These values are similar to those reported for pumpellyite-chlorite mineral pairs in rocks under prehnite-pumpellyite facies metamorphism in other low grade metamorphic terrains (e.g., Robinson and Bevins, 1986; Bevins and Robinson, 1993, 2003). Although it has been established in other areas that the Abanico Formation reaches zeolite facies in its upper parts (Levi, 1970; Bevins et al., 2003; Robinson et al., 2004), this would not be the case at the localities studied here considering the ubiquitous presence of epidote and the absence of zeolites in metamorphic mineral assemblages throughout the entire exposed series. 


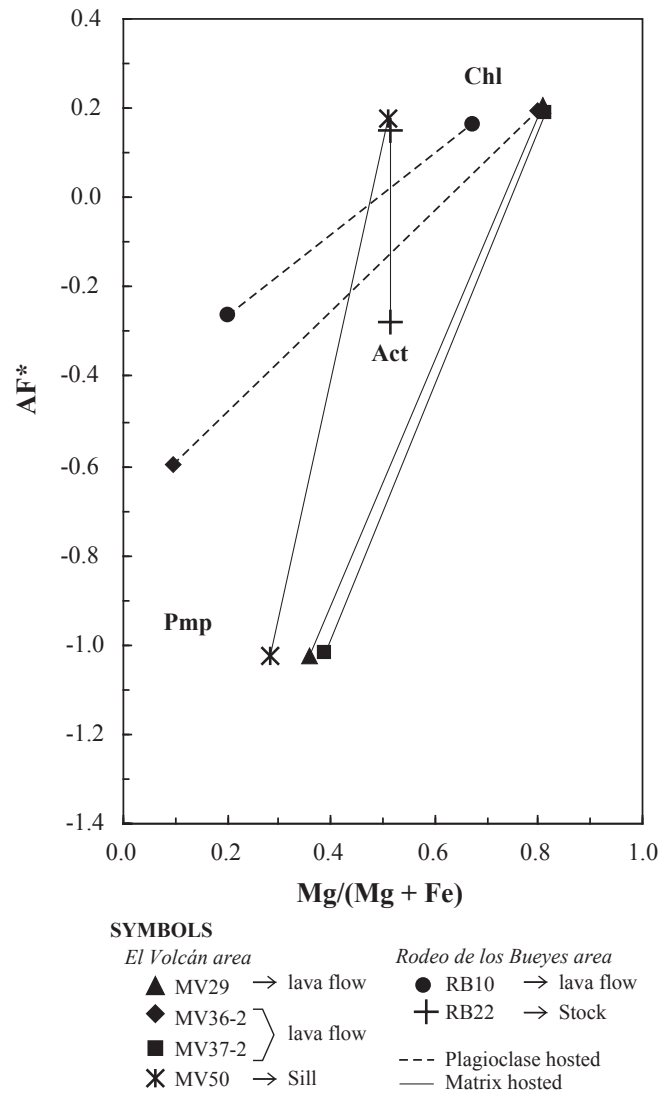

FIG. 6. Epidote projection for mean chlorite-pumpellyite and actinolite-chlorite coexisting pairs shown in figure 5 for the samples from the El Volcán and Rodeo de los Bueyes areas.

The presence of actinolite in metamorphic mineral assemblages, as seen here in sample RB22 from Rodeo de los Bueyes area, has been widely reported in low grade metamorphic terrains under subgreenschists facies metamorphism (e.g., Springer et al., 1992; Beiersdorfer, 1993; Bevins and Robinson, 1993, 2003; Day and Springer, 2005). Moreover, it has been shown that calcic amphibole may be stable almost over the entire pumpellyite and prehnite stability fields (Frey et al., 1991) although its presence seems to be restricted to an appropriate bulk compositional control. Bevins and Robinson (1993) have shown for the Welsh Basin that actinolite is notably absent in metamorphic mineral assemblages of metabasites under prehnitepumpellyite facies. This absence of actinolite is independent of the $\mathrm{MgO} /(\mathrm{MgO}+\mathrm{FeO})$ ratio of the host rock, indicated by the $\mathrm{MgO} /(\mathrm{MgO}+\mathrm{FeO})$ ratio in chlorite. Actinolite is reported to first appear in metabasites from the transition between prehnitepumpellyite to greenschists facies in rocks with an $\mathrm{MgO} /(\mathrm{MgO}+\mathrm{FeO})>0.54$, with less magnesian compositions showing pumpellyite instead of actinolite in the mineral assemblages. Beiersdorfer (1993) reported a similar situation for metabasites of the Smartville Complex, Sierra Nevada, but with a higher transitional $\mathrm{MgO} /(\mathrm{MgO}+\mathrm{FeO})$ of 0.63-0.65. In all these mineral assemblages actinolite-chlorite $\mathrm{K}_{\mathrm{D}}$ shows mean values between 1.06-1.10, in contrast with values higher than 1.2 shown by these assemblages developed under greenschists facies metamorphism (Bevins and Robinson, 1993, 2003) or values lower than unity which are considered not

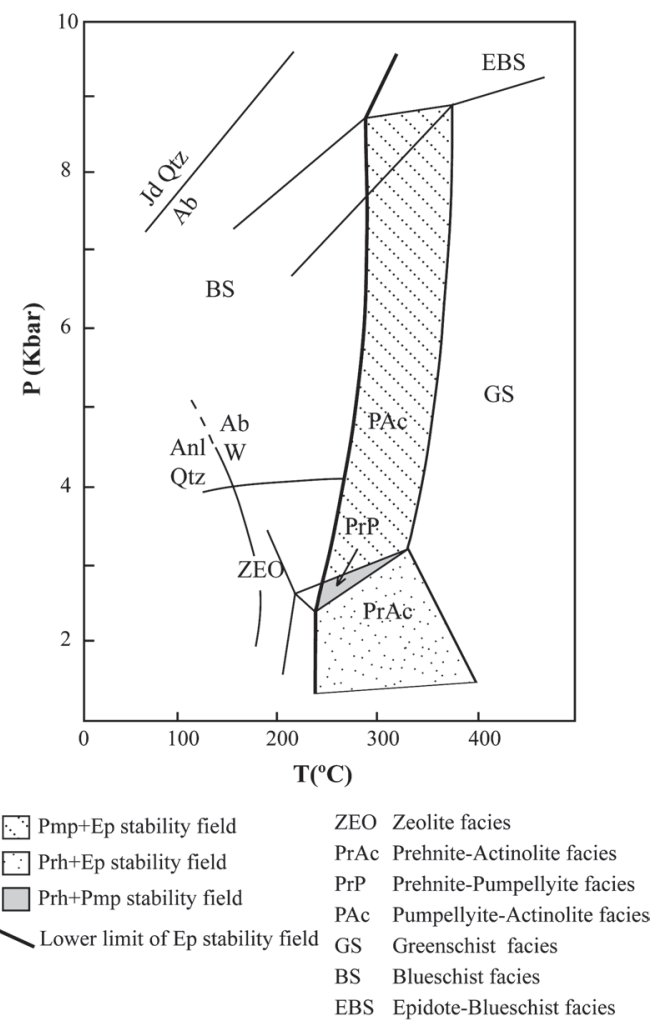

FIG. 7. Petrogenetic grid for low-grade metabasites in the NCMASH basaltic model with excess of water, chlorite, albite and quartz (after Liou et al., 1987; modified by Beiersdorfer and Day, 1995). Stability fields of mineral assemblages present in the studied areas are highlighted. Pmp: pumpellyite; Ep: epidote; Prh: prehnite; Jd: jadeite; Qtz: quartz; Ab: albite; Anl: analcime; W: water. 
representative of regional low-grade metamorphism (Robinson et al., 2004). Actinolite-chlorite $\mathrm{K}_{\mathrm{D}}$ of mineral assemblages studied here show a range between 1.03-1.14 which is remarkably consistent with those reported for rocks under subgreenschists facies metamorphism. However, the presence of actinolite in sample $\mathrm{RB} 22$ at a mean $\mathrm{MgO}$ / $(\mathrm{MgO}+\mathrm{FeO})$ chlorite value of 0.48 contrasts with the compositional controls mentioned above since this corresponds to the less magnesian composition and all the metamorphic assemblages developed above this value contain exclusively pumpellyite.

Springer et al. (1992) reported the presence of actinolite or pumpellyite in mineral assemblages of rocks under prehnite-pumpellyite facies of the Smartville Complex, Sierra Nevada, in a wide and overlapping range of $\mathrm{MgO} /(\mathrm{MgO}+\mathrm{FeO})$ compositions. According to these authors, in $\mathrm{Al}$ - and $\mathrm{Fe}$ - rich compositions pumpellyite is a common additional phase, amphibole is a common additional phase in $\mathrm{Al}$-poor and $\mathrm{Fe}$-rich composition, and in magnesian compositions both phases develop. Considering chlorites as a proxy for the whole rock composition, actinolites studied here are effectively developed in most Al-poor compositions (Table 1), but it still remains a discrepancy concerning its absence in the metamorphic assemblages developed in magnesian composition. Although actinolites in mineral assemblages of sample RB22 show several textural and chemical characteristics that suggest a metamorphic origin, it is not straightforward to explain their presence by a direct comparison with secondary assemblages of rocks under prehnite-pumpellyite facies in other metamorphic terrains with which they share many, but not all, the reported chemical characteristics. Additionally, the fact that this mineral is present in only one sample precludes its association with a reliable chemical pattern. Day and Springer (2005) have indicated that the presence or absence of actinolite in rocks containing pumpellyite or prehnite can be controlled in part by chemical compositions for which low $\mathrm{MgO}$ contents or high $\mathrm{Al}_{2} \mathrm{O}_{3}$ contents might explain the absence of this mineral. Insofar as actinolites in sample RB22 are metamorphic in origin, their presence might be the result of the Alpoor composition of the rock where they develop in contrast to their absence in Al-rich rocks of more magnesian compositions which, instead, contain pumpellyite (Table 1).

\section{Metamorphic conditions}

\subsection{P-T Conditions}

A first qualitative method for estimating P-T conditions of metamorphism is the use of petrogenetic grids based on mineral assemblages. The petrogenetic grid for low-grade metabasites determined by Liou et al. $(1985,1987)$, and later modified by Beiersdorfer and Day (1995) is a semi-quantitative grid based on the NCMASH $\left(\mathrm{Na}_{2} \mathrm{O}-\mathrm{CaO}-\mathrm{MgO}-\right.$ $\mathrm{Al}_{2} \mathrm{O}_{3}-\mathrm{SiO}_{2}-\mathrm{H}_{2} \mathrm{O}$ ) basaltic model which describes the relation between $\mathrm{P}, \mathrm{T}$, and low-grade metamorphic mineral assemblages (Fig. 7). In this grid, the P-T field covered by mineral assemblages representative of the prehnite-pumpellyite facies metamorphism ranges around 2.3-3 kbar and $200^{\circ}-350^{\circ} \mathrm{C}$ (Fig. 7). Several later studies have attempted to overcome the inadequacies of this grid with respect to observed natural low-grade mineral assemblages by taking into account chemical and thermodynamic data. Frey et al. (1991) developed a petrogenetic grid based on an internally consistent thermodynamic data set for end-member mineral compositions. On this basis, they showed that the prehnite-pumpellyite stability field covers a range of $\mathrm{P}-\mathrm{T}$ conditions between 2-3.4 $\mathrm{Kbar}$ and $200^{\circ}-280^{\circ} \mathrm{C}$. Moreover, based on the study of natural mineral assemblages, they also highlighted the important effect of whole rock/mineral composition in defining the P-T field of a metamorphic facies, showing that there is extensive overlap in P-T space among critical mineral assemblages. In this context, they showed that the prehnite-pumpellyite facies could extend at least up to a P-T range of $175^{\circ}-280^{\circ} \mathrm{C}$ and $0.5-4.5 \mathrm{Kbar}$. These latter values constitute a rough basis for the P-T conditions of the low-grade metamorphic mineral assemblages developed in Abanico East formation.

Thermobarometry applied to metamorphic rocks is usually based on mineral composition and/or partition of elements between coexisting phases. Caution is required, however, when applying this approach to low-grade metamorphic minerals considering that their composition usually, at best, represents the state of the reaction progress rather than a state of thermodynamic equilibrium, a necessary condition for the application of any thermobarometer. Pressure estimates can be roughly approached by actinolite composition. Geobarometer of Brown (1977) has been used on these minerals in association with the 
buffer assemblage albite+chlorite+iron oxide and indicates pressures inferior to 3 or 2 kbar for the maximum $\mathrm{Fe}^{3+}$ and minimum $\mathrm{Fe}^{3+}$ calculation methods of actinolite structural formula, respectively. Cathelineau's (1988) geothermometer applied to all the analyzed chlorites indicates a temperature range of $92^{\circ}-319^{\circ} \mathrm{C}$ and shows no pattern of variation with the stratigraphic height. When applied only to the composition of chlorites with $\mathrm{X}_{\mathrm{C}}>0.75$ and present in low variance mineral assemblages coexisting with pumpellyite or actinolite, plus the ubiquitous phases, the range is restricted to temperatures between $200^{\circ}-309^{\circ} \mathrm{C}$. The highest and lowest temperatures are recorded in sample MV29, near de base of the studied succession, and sample RB10, the stratigraphically highest sample of the group, respectively (Fig. 2). Additionally, another temperature estimate can be obtained from sample RB22 for which the secondary mineral assemblage composed of prehnite + actinolite + epidote + chlorite + albite + quartz defines an equilibrium metamorphic reaction that is nearly independent of pressure. Thermodynamic modelling was performed in the NCFMASH system with the GEO-CALC software (Berman et al., 1987) using the thermodynamic data base from Berman (1988) and the activity models of Powell et al. (1993). This modelling considered chemical composition of secondary minerals from sample RB22 with the exception of epidote for which we used an average of all analyses of this mineral from both areas. A temperature of $312^{\circ}-320^{\circ} \mathrm{C}$ was obtained for this reaction between 2-3 kbar. Varying the epidote composition in the range defined by all the analyses has a negligible effect on the calculated temperature. Both chemical and thermodynamic estimates of temperature are in reasonable agreement with the temperature range of $175^{\circ}-280^{\circ} \mathrm{C}$ estimated for the prehnite-pumpellyite facies by Frey et al. (1991).

\subsection{Metamorphic fluids $\mathrm{X}_{\mathrm{CO}_{2}}$}

As seen in epidote projection diagrams and in the previous discussion, both studied localities show an overall chemical coherency. However, particular mineral occurrences restricted to each area indicate local differences in metamorphic conditions since the host lithology remains essentially the same between them. As mentioned earlier, the most noticeable of these differences is the ubiquitous presence of calcite and scarcity of prehnite in secondary mineral assemblages at the El Volcán area while the inverse situation is seen at the Rodeo de los Bueyes area. Digel and Ghent (1994) have shown for metabasites under prehnite-pumpellyite facies metamorphism in the Flin Flon area, Canada, that only for fluids with low $\mathrm{X}_{\mathrm{CO}_{2}}<0.002$ prehnite and, to a lesser extent, pumpellyite are stable. Additionally, the P-T stability field of assemblages containing these two phases is extremely small. For higher $\mathrm{X}_{\mathrm{CO}_{2}}$ contents, the stability field of assemblages containing calcitechlorite-epidote are stable and their stability field widens with increasing $\mathrm{X}_{\mathrm{CO}_{2}}$ at the expense of those containing prehnite or pumpellyite. Assemblages containing calcite-chlorite-epidote are ubiquitous throughout the series exposed at the El Volcán area. Here the occurrence of pumpellyite or prehnite in mineral assemblages is restricted to 5 and 1 samples, respectively. This suggests that overall $\mathrm{X}_{\mathrm{CO}_{2}}$ contents of metamorphic fluids in this area where high suppressing pumpellyite and prehnite formation, since the composition of the host metabasalts shows no major changes throughout the series. The presence of these mineral phases in particular samples is probably related to local favourable fluid $\mathrm{X}_{\mathrm{CO}_{2}}$ contents. On the contrary, at the Rodeo de los Bueyes area $\mathrm{X}_{\mathrm{CO}_{2}}$ contents of fluids must have remained low enough to permit the widespread development of prehnite as observed. This local difference in metamorphic conditions might well be related to particular characteristics of each succession, e.g., a higher sedimentary rock/volcanic rock ratio, which are likely to develop locally in an area with the interplay of subsidence, sedimentation and volcanic activity.

\section{Conclusions}

In order to deal in depth with the low-grade metamorphism affecting the Abanico Formation, we have carried out a detailed petrographic and chemical study of its secondary mineralogy throughout a continuous section of this formation exposed in two localities: the El Volcán and Rodeo de los Bueyes areas. Mineral chemistry, in terms of overall composition, compositional variability, and element partitioning between coexisting minerals, indicates that the secondary minerals do not correspond to fully equilibrated phases. This is also highly dependent on the metadomain where these phases develop, especially in the case of pumpellyite. Mixed-layer chlorite-smectite and actinolite are the phases that 
most closely represent the whole rock effective bulk composition, independent from the metadomain where they are hosted. Compared to these minerals, pumpellyite always shows evidence of being a less equilibrated phase. Additionally, its composition more closely reflects the whole rock effective bulk composition only when it grows in the matrix while composition of pumpellyite hosted in plagioclase crystals are biased by a metadomain compositional control. Despite this, secondary mineral assemblages and mineral chemistry suggest that reactions have ocurred equivalently in both studied localities. Additionally, a chemical difference in $\mathrm{CO}_{2}$ contents of metamorphic fluids has been identified between both areas which controls the presence of minerals such as calcite and prehnite in the metamorphic mineral assemblages.

Mineral assemblages are indicative of prehnitepumpellyite facies metamorphism, as it has been previously established for Abanico Formation in other localities in central Chile (Levi, 1970; Aguirre et al., 1978; Sellés, 1999; Bevins et al., 2003; Robinson et al., 2004). Pressure and temperature of this metamorphic event have been roughly estimated to be lower than $3 \mathrm{kbar}$ and $320^{\circ} \mathrm{C}$, respectively.

\section{Acknowledgments}

Financial support from the FONDECYT Project 1020809 and ECOS/CONICYT C03U01 are gratefully acknowledged. The authors are grateful to Dr. R. Charrier (Departamento de Geología, Universidad de Chile) and Dr. B. Levi (Stockholm, Sweden) for useful collaboration in the field work and helpful comments and suggestions during the development of this work. The authors thank Drs. R. Bevins and H.D. Day for their constructive review, comments and Dr D. Morata for his review comments and kind aid in the thermodynamic modelling.

\section{References}

Aguirre, L. 1960. Geología de los Andes de Chile central (Provincia de Aconcagua). Instituto de Investigaciones Geológicas, Boletín 9: 70 p. Santiago.

Aguirre, L.; Levi, B.; Offler, R. 1978. Unconformities as mineralogical breaks in the burial metamorphism of the Andes. Contributions to Mineralogy and Petrology 66: 361-366

Aguirre, L.; Levi, B.; Nyström, J.O. 1989. The link between metamorphism, volcanism and geotectonic setting during the evolution of the Andes. In Evolution of metamorphic belts (Daly, J.S.; Cliff, R.A.; Yardley, B.W.D.; editors). Geological Society, Special Publication 43: 223-232.

Aguirre, L.; Robinson, D.; Bevins, R.E.; Morata, D.; Vergara, M.; Fonseca, E.; Carrasco, J. 2000. A lowgrade metamorphic model for the Miocene volcanic sequences in the Andes of central Chile. New Zealand Journal of Geology and Geophysics 43: 83-93.

Ancey, M.; Bastenaire, F.; Tixier, R. 1978. Applications of statistical methods in microanalyses. In Microanalysis and scanning electron microscopy (Maurice, F.; Meny, L.; Tixier, R.; editors). Proceedings of Summer School St. Martin-d'Heres, Les Éditions de Physique, Orsay: 319-343.

Atherton, M.P.; Aguirre, L. 1992. Thermal and geotectonic setting of the Cretaceous volcanic rocks near Inca, Perú, in relation to Andean crustal thining. Journal of South American Earth Sciences 5: 47-79.

Aubouin, J.; Borrelo, A.V.; Ceccioni, G.; Charrier, R.; Chotin, P.; Frutos, J.; Thiele, R.; Vicente, J.C. 1973. Esquisse paléogéographique et structurale des Andes Méridioneles. Revue de Géographique Physique et Géologie Dynamique 15: 11-72.

Baeza, O. 1999. Análisis de litofacies, evolución depositacional y análisis estructural de la Formación Abanico en el área comprendida entre los ríos Yeso y Volcán, Región Metropolitana. Thesis (Unpublished), Universidad de Chile, Departamento de Geología: 120 p. Santiago.

Beiersdorfer, R.E. 1993. Metamorphism of a Late Jurassic volcano-plutonic arc, Northern California, U.S.A. Journal of Metamorphic Geology 11: 415-428.

Beiersdorfer, R.E.; Day, H.W. 1995. Mineral parageneses of pumpellyite in low-grade mafic rocks. In Low-Grade Metamorphism of Mafic Rocks (Schiffman, P.; Day, H.W.; editors). Geological Society of America Special Paper (296): 5-28.

Belmar, M. 2000. Low-grade metamorphism in Central Chile at $35^{\circ} \mathrm{S}$. Ph.D. Thesis (Unpublished), University of Basel: 189 p. Basel.

Berman, R.G.; Brown, T.H.; Perkins, E.H. 1987. GEOCALC: software for calculation and display of pressure-temperature-composition phase diagrams. American Mineralogist 72: 861-862.

Berman, R.G. 1988. Internally-consistent thermodynamic data for minerals in the $\mathrm{Na}_{2} \mathrm{O}-\mathrm{K}_{2} \mathrm{O}-\mathrm{CaO}-\mathrm{MgO}-\mathrm{FeO}-$ $\mathrm{Fe}_{2} \mathrm{O}_{3}-\mathrm{Al}_{2} \mathrm{O}_{3}-\mathrm{SiO}_{2}-\mathrm{TiO}_{2}-\mathrm{H}_{2} \mathrm{O}-\mathrm{CO}_{2}$. Journal of Petrology 29: 445-522.

Bettison, L.A.; Schiffman, P. 1988. Compositional and structural variation of the phyllosilicates from the 
Point Sal ophiolite, California. American Mineralogist 73: 62-76.

Bevins, R.E.; Merriman, R.J. 1988. Compositional controls on coexisting prehnite-actinolite and prehnite-pumpellyite facies assemblages in the Tal y Fan metabasite intrusion, North Wales: implications for Caledonian metamorphism field gradients. Journal of Metamorphic Geology 6: 17-39.

Bevins, R.E.; Robinson, D. 1993. Parageneses of Ordovician sub-greenschist to greenschist facies metabasites from Wales, U.K. European Journal of Mineralogy 5: 925-935.

Bevins, R.E.; Robinson, D. 1995. Regional low-grade polygenetic metamorphism and inversion in the northern part of the Eastern Belt, northern Sierra Nevada, California. In Low-Grade Metamorphism of Mafic Rocks (Schiffman, P.; Day, H.W.; editors). Geological Society of America Special Paper 296: 29-50.

Bevins, R.E.; Robinson, D. 2003. Mineral parageneses in low-grade metabasites at low pressures and consideration of the sub-greenschist realm. In Diagenesis and Low-Temperature Metamorphism. Theory, Methods and Regional Aspects. Seminarios de la Sociedad Española de Mineralogía 3: 9-20. Madrid.

Bevins, R.E.; Robinson, D.; Aguirre, L.; Vergara, M. 2003. Episodic burial metamorphism in the Andes-A viable model? Geology 31: 705-708.

Brown, E.H. 1977. The crossite content of Ca-amphibole as a guide to pressure of metamorphism. Journal of Petrology 18: 53-72.

Bustamante, M.A. 2001. Análisis del contacto Meso-Cenozoico en el valle del río Volcán, Cordillera de los Andes de la Región Metropolitana. Thesis (Unpublished), Universidad de Chile, Departamento de Geología: 54 p. Santiago.

Cathelineau, M. 1988. Cation site occupancy in chlorite and illites as a function of temperatura. Clay Minerals 23: 471-485.

Coombs, D.S. 1961. Some recent work on the lower grades of metamorphism. Australian Journal of Science 24: 203-215.

Coombs, D.S.; Nakamura, Y.; Vuangnat, M. 1976. Pumpellyite-actinolite facies schists of the Taveyanne Formation near Loèche, Valais, Switzerland. Journal of Petrology 17: 440-471.

Charrier, R.; Baeza, O.; Elgueta, S.; Flynn, J.J.; Gana, P.; Kay, S.M.; Muñoz, N.; Wyss, A.R.; Zurita, E. 2002. Evidence for Cenozoic extensional basin development and tectonic inversion south of the flat-slab segment, southern Central Andes, Chile (33 $3^{\circ}-36^{\circ}$ S.L.). Journal of South American Earth Sciences 15: 117-139.

Cho, M.; Liou, J.G.; Maruyama, S. 1986. Transition from the zeolite to prehnite-pumpellyite facies in the Karmutsen metabasites, Vancouver Island, British Columbia. Journal of Petrology 28: 417-443.

Day, H.W.; Springer, R.K. 2005. The first appearance of actinolite in the prehnite-pumpellyite facies, Sierra Nevada, California. The Canadian Mineralogist 43: 89-101.

Digel, S.; Ghent, E.D. 1994. Fluid-mineral equilibria in prehnite-pumpellyite to greenschists facies metabasites near Flin Flon Manitoba, Canada: implications for petrogenetic grids. Journal of Metamorphic Geology 12: 467-477.

Drake, R.E.; Vergara, M.; Munizaga, F.; Vicente, J.C. 1982. Geochronology of Mesozoic-Cenozoic Magmatism in Central Chile, Lat. $31^{\circ}-36^{\circ} \mathrm{S}$. Earth-Science Reviews 18: 353-363.

Fock, A. 2005. Cronología y tectónica de la exhumación en el Neógeno de los Andes de Chile central entre $\operatorname{los} 33^{\circ}$ y los $34^{\circ} \mathrm{S}$. M.Sc. (Unpublished), Universidad de Chile, Departamento de Geología: 179 p. Santiago.

Frey, M.; De Capitani, C.; Liou, J.G. 1991. A new petrogenetic grid for low grade metabasites. Journal of Metamorphic Geology 9: 497-509.

Frey, M.; Robinson, D. 1999. Low-Grade Metamorphism. Blackwell Science: 312 p. Oxford.

Fuentes, F. 2004. Petrología y metamorfismo de muy bajo grado de unidades volcánicas oligo-miocenas en la ladera occidental de los Andes de Chile Central $\left(33^{\circ} \mathrm{S}\right)$. Ph.D. (Unpublished), Universidad de Chile, Departamento de Geología: 398 p. Santiago.

Godoy, E.; Yáñez, G.; Vera, E. 1999. Inversion of an Oligocene volcano-tectonic basin and uplifting of its superimposed Miocene magmatic arc in the Chilean Central Andes: first seismic and gravity evidences. Tectonophysics 306: 117-736.

González, O. 1963. Observaciones geológicas en el valle del Río Volcán. Universidad de Chile, Departamento de Geología, Revista Minerales 17: 20-61. Santiago.

Hey, M.H. 1954. A new review of the chlorites. Mineralogical Magazine 30: 272-292.

Kawachi, Y. 1975. Pumpellyite-actinolite and contiguous facies metamorphism in part of upper Wakatipu district, South Island, New Zealand. New Zealand Journal of Geology and Geophysics 18: 140-441.

Kay, S.M.; Mpodozis, C.; Coira, B. 1999. Neogene magmatism, and mineral deposits of the Central Andes 
$\left(22^{\circ}-33^{\circ} \mathrm{S}\right.$ latitude). In Geology and Ore Deposits of the Central Andes (Skiner, B.J.; editor). Society of Economic Geologists Special Publication 7: 27-59.

Kay, S.M.; Mpodozis, C. 2002. Magmatism as a probe to the Neogene shallowing of the Nazca plate beneath the modern Chilean flat-slab. Journal of South American Earth Sciences 15: 39-57.

Kay, S.M.; Godoy, E.; Kurtz, A. 2005. Episodic arc migration, crustal thickening, subduction erosion, and magmatism in the south-central Andes. Geological Society of America Bulletin 117: 67-88.

Klohn, C. 1960. Geología de la Cordillera de los Andes de Chile (Provincias de Santiago, Colchagua y Curicó). Instituto de Investigaciones Geológicas, Boletín 8: 95 p. Santiago.

Kurtz, A.; Kay, S.M.; Charrier, R.; Farrar, E. 1997. Geochronology of Miocene plutons and exhumation history of the El Teniente region, Central Chile (34 ${ }^{\circ}$ $\left.35^{\circ} \mathrm{S}\right)$. Revista Geológica de Chile 24: 75-90.

Levi, B. 1969. Burial metamorphism of a Cretaceous volcanic sequence west from Santiago, Chile. Contributions to Mineralogy and Petrology 24: 30-49.

Levi, B. 1970. Burial metamorphic episodes in the Andes Geosyncline, central Chile. Geologishe Rundschau 59: 994-1013.

Levi, B.; Aguirre, L.; Nyström, J.O.; Padilla, H.; Vergara, M. 1989. Low-grade regional metamorphism in the Mesozoic-Cenozoic volcanic sequences of the central Chile Andes. Journal of Metamorphic Geology 7: 487-495.

Liou, J.G.; Ernst, W.G. 1979. Oceanic ridge metamorphism of the East Taiwan Ophiolite. Contributions to Mineralogy and Petrology 68: 335-342.

Liou, J.G.; Maruyama, S.; Cho, M. 1985. Phase equilibria and mineral parageneses of metabasites in low-grade metamorphism. Mineralogical Magazine 49: 321-333.

Liou, J.G.; Maruyama, S.; Cho, M. 1987. Very lowgrade metamorphism of volcanic and volcanoclastic rocks-Mineral assemblages and mineral facies. In Low Temperature Metamorphism (Frey, M.; editor). Blackie \& Sons: 59-113. Glasgow.

Merlet, C. 1994. An accurate computer program for quantitative electron microprobe micro-analysis. Microchimica, Acta 114: 363-376.

Munizaga, F.; Vicente, J.C. 1982. Acerca de la zonación plutónica y del volcanismo Miocénico en los Andes del Aconcagua (Lat. $\left.32^{\circ}-33^{\circ} \mathrm{S}\right)$. Datos radiométricos K-Ar. Revista Geológica de Chile 16: 3-21.
Muñoz, M. 2005. Geoquímica, metamorfismo y petrogénesis de la franja oriental de la Formación Abanico en Chile Central, área de El Volcán, Cajón del Maipo (3350'S, $70^{\circ} 12^{\prime}-70^{\circ} 05^{\prime}$ W). M.Sc. Thesis (Unpublished), Universidad de Chile, Departamento de Geología: 172 p. Santiago.

Muñoz, M.; Fuentes, F.; Vergara, M.; Aguirre, L.; Nyström, J.O.; Fèraud, G.; Demant, A. 2006. Abanico East Formation: petrology and geochemistry of volcanic rocks behind the Cenozoic arc front in the Andean Cordillera, central Chile (3350'). Revista Geológica de Chile 33(1): 109-140.

Nyström, J.O.; Vergara, M.; Morata, D.; Levi, B. 2003. Tertiary volcanism in central Chile $\left(33^{\circ} 15^{\prime}-33^{\circ} 45^{\prime} \mathrm{S}\right)$; a case of Andean Magmatism. Geological Society of America, Bulletin 115: 1523-1537.

Offler, R.; Aguirre, L.; Levi, B.; Child, S. 1980. Burial metamorphism in rocks of the western Andes of Perú. Lithos 13: 31-42.

Pe-Piper, G. 1985. Dioctahedral micas in Triassic metavolcanic rocks of western Greece. Canadian Mineralogist 23: 597-608

Powell, W.G.; Carmichael, D.M.; Hodgson, C.J. 1993. Thermobarometry in a subgreenschist to greenschist transition in metabasites of the Abitibi greenstone belt, Superior Province, Canada. Journal of Metamorphic Geology 11: 165-178.

Robinson, D.; Bevins, R.E. 1986. Incipient metamorphism in the Lower Paleozoic marginal basin of Wales. Journal of Metamorphic Geology 4: 101-113.

Robinson, D. 1987. The transition from diagenesis to metamorphism in extensional and collisional settings. Geology 15: 866-869.

Robinson, D.; Bevins, R.E.; Aguirre, L.; Vergara, M. 2004. A reappraisal of episodic burial metamorphism in the Andes of central Chile. Contributions to Mineralogy and Petrology 146: 513-528.

Schiffman, P.; Fridleifsson, G.O. 1991. The smectitechlorite transition in drillhole NJ-15, Nesjavellir geothermal field, Iceland: XRD, BSE and electron microprobe investigations. Journal of Metamorphic Geology 9: 679-696.

Sellés, D. 1999. La Formación Abanico en el Cuadrángulo

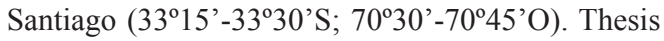
(Unpublished), Universidad de Chile, Departamento de Geología: 154 p. Santiago.

SERNAGEOMIN. 2002. Mapa Geológico de Chile: versión digital. Servicio Nacional de Geología y Minería, Publicación Geológica Digital, No. 4 (CD-ROM, 1.0, 2003). Santiago, Chile. 
Springer, R.K.; Day, H.W.; Beiersdorfer, R.E. 1992. Prehnite-pumpellyite to greenschist facies transition, Smartville Complex, near Auburn, California. Journal of Metamorphic Geology 10: 147-170.

Vergara, M.; Drake, R.E. 1979. Edades K/Ar en secuencias volcánicas continentales postneocomianas de Chile Central; su depositación en cuencas intermontanas restringidas. Revista de la Asociación Geológica Argentina 34: 42-52.

Vergara, M.; Charrier, R.; Munizaga, F.; Rivano, S.; Sepúlveda, P.; Thiele, R.; Drake, R.E. 1988. Miocene volcanism in the central Chilean Andes (3130'S$34^{\circ} 35^{\prime}$ S). Journal of South American Earth Sciences 1: 199-209.
Vergara, M.; Levi, B.; Villarroel, R. 1993. Geothermaltype alteration in a burial metamorphosed volcanic pile, central Chile. Journal of Metamorphic Geology 11: 449-454.

Vergara, M.; Morata, D.; Villarroel, R.; Nyström, J.O.; Aguirre, L. 1999. ${ }^{40} \mathrm{Ar} /{ }^{39} \mathrm{Ar}$ ages, very low grade metamorphism and geochemistry of the volcanic rocks from "Cerro El Abanico", Santiago Andean Cordillera

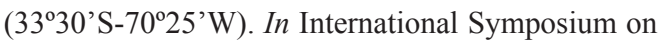
Andean Geodynamics, No. 4, Extended Abstracts: 785-788. Göttingen.

Zen, E.-A. 1961. The zeolite facies: an interpretation. American Journal of Sciences 259: 402-409.

Manuscript received: December 2, 2008; revised/accepted: May 28, 2009. 